\title{
The evolution of the upright posture and gait - a review and a new synthesis
}

\author{
Carsten Niemitz
}

Received: 26 March 2009/Revised: 27 November 2009 / Accepted: 2 December 2009/Published online: 3 February 2010

(C) The Author(s) 2010. This article is published with open access at Springerlink.com

\begin{abstract}
During the last century, approximately 30 hypotheses have been constructed to explain the evolution of the human upright posture and locomotion. The most important and recent ones are discussed here. Meanwhile, it has been established that all main hypotheses published until the last decade of the past century are outdated, at least with respect to some of their main ideas: Firstly, they were focused on only one cause for the evolution of bipedality, whereas the evolutionary process was much more complex. Secondly, they were all placed into a savannah scenario. During the 1990s, the fossil record allowed the reconstruction of emerging bipedalism more precisely in a forested habitat (e.g., as reported by Clarke and Tobias (Science 269:521-524, 1995) and WoldeGabriel et al. (Nature 412:175-178, 2001)). Moreover, the fossil remains revealed increasing evidence that this part of human evolution took place in a more humid environment than previously assumed. The Amphibian Generalist Theory, presented first in the year 2000, suggests that bipedalism began in a wooded habitat. The forests were not far from a shore, where our early ancestor, along with its arboreal habits, walked and waded in shallow water finding rich food with little investment. In contrast to all other theories, wading behaviour not only triggers an upright posture, but also forces the individual to maintain this position and to walk bipedally. So far, this is the only scenario suitable to overcome the considerable anatomical and functional threshold from quadrupedalism to bipedalism. This is
\end{abstract}

C. Niemitz $(\bowtie)$

Institut für Humanbiologie und Anthropologie,

Freie Universität Berlin,

Albrecht-Thaer-Weg 6,

14195 Berlin, Germany

e-mail: humanbio@zedat.fu-berlin.de consistent with paleoanthropological findings and with functional anatomy as well as with energetic calculations, and not least, with evolutionary psychology. The new synthesis presented here is able to harmonise many of the hitherto competing theories.

Keywords Orthograde posture - Bipedalism - Upright gait . Shore dwelling · Evolution

\section{Introduction}

The habitual orthograde human posture and locomotion using harmonic cycles of anatomical pendulums are unique among all mammals (e.g., Gebo 1996; Schmitt 2003; Vaughan 2003). Even among all land-dwelling vertebrates, human bipedalism is unparalleled, since erect-walking penguins, with their short rudder-like feet, have a completely different functional anatomy and biomechanics (cf. Griffin and Kram 2000). Moreover, neither dinosaurs nor ostriches or any other sauropsid or marsupial moving on their hind feet show an orthograde spine in locomotion (Niemitz 2004). During Miocene evolution, there appeared several fossil primates showing, to various degrees, adaptations for an orthograde posture (Nakatsukasa et al. 2000, 2004; see also MacLatchy et al. 2000) In the Late Miocene, the long-armed Oreopithecus bamboli may have developed a kind of terrestrial bipedalism in the absence of predators that was very different from the human one (Köhler and Moyà-Solà 1997a; Rook et al. 1999; Sénut 2007), although the debate on this topic is still going on: "Its locomotion has been variously reconstructed as slothlike, ape-like, and human-like, and it has been placed in almost every possible catarrhine group, from the cercopithecoids to the hominins" (Cartmill et al. 2009). At any 
rate, later on, upright human bipedalism remained unique as another habitual orthograde walker and runner does not exist.

The manifold hypotheses and theories on the evolution of human upright posture and gait have their own intriguing history. Until the early 1990s, the evolutionary development of human bipedalism was placed into a savannah scenario (e.g., Rose 1976; Blumenshine and Cavallo 1992). Later, most authors agreed that the evolution from a quadrupedal to a bipedal ancestor of extant humans occurred in a forested landscape (e.g., Haile-Selassie 2001; Sénut and Pickford 2004). As early as in 1989, Marean had even postulated that fully erect members of the genus Homo left woodland habitats in order to use more open vegetation not longer ago than after 1.6 Ma. The sheer number of different hypotheses proposed to the scientific community show that each of them was published, because their respective author was not convinced by the hitherto known theories, adding another one her- or himself, which, again, did not satisfy other researchers.

During the last 4 years, two articles appeared which discussed the evolution of the upright human posture and locomotion from a perspective different from the one chosen here. While Preuschoft (2004) concentrates on biomechanics, Crompton et al. (2008) focus on paleoanatomy. Moreover, two new explanations for the evolution of human bipedalism appeared (Sylvester 2006; Skoyles 2006), which will also be discussed later in this text. But still, most of the recently emerged theories did not automatically devalue former theories in part or as a whole, and many of them produced respectable grounds, or at least partly, uncontested arguments. These hypotheses may serve as constructive elements for the synthesis of a conciliatory, updated theoretical construction. After a theoretical outlook and a discussion of some Miocene and later hominoid and hominid fossils, this article presents an evaluation and discussion of the more influential, and finally, the more recent hypotheses, aiming to reconcile quite a number of aspects of the various theories.

\section{Disadvantages of bipedal locomotion for quadrupedal} primates

Our ancestors would have probably become extinct if they were not adapted to their specific temporal environment, where they developed their bipedal habits including the corresponding transitional behavioural constraints. This is an important statement, because the change from a quadrupedal to a bipedal forerunner of extant humans has most often been considered from the perspective that an upright stance might have offered specific favours or positive selective values. Hunt (1994), however, discussing "less than optimal adaptation to bipedal locomotion" in australopithecines, summarises: "Locomotor inefficiency (my italics) supports the hypothesis that bipedalism evolved more as a terrestrial feeding posture than as a walking adaptation." Other authors emphasise that, in the first place, the adoption of an erect posture for a quadrupedal primate would reduce speed and agility (Taylor and Rowntree 1973; Lovejoy 1981; Niemitz 2004).

Therefore, we want to propose to consider the problem from a decisively different viewpoint and to put it more precisely than above:

Which environmental conditions offered new functional, and therefore, evolutionary advantages to our "transitional quadrupedal-bipedal ancestors"? And consequently: "Which circumstances overcompensated, at the same time, the disadvantages of orthograde bipedal locomotion?"

Although a forested habitat seems to be the best scenario for the evolution of bipedalism, the disadvantages mentioned here would apply as well to a savannah environment. The functional disadvantages, our quadrupedal ancestors had to tackle when walking upright, may be summarised as follows (Niemitz 2007):

- Slowness (Lovejoy 1981) bears three main disadvantages:

1. Reduced velocity increases predatory pressure (e.g., against eagles (Tobias, personal communication) or leopards; see: the robust australopithecine calvarium SK-54 with leopard punctures in its skull)

2. It causes stress on the time budget for foraging and

3. for social interactions. In cercopithecid and hominoid societies, social interactions (like grooming sessions, male buffering and coalition behaviour, allomothering, and many other behavioural patterns) are highly time consuming. Since human communication and social interactions are, together with an enormous enlargement of corresponding neocortex structures, by far the most complicated ones not only among primates, this evolution certainly afforded a great portion of daily activities also for our ancestors over a long period of time.

- The locomotor apparatus is not yet fully adapted to the labile, high position of the centre of mass of the upright body above a small supporting area. This increases the probability of injuries from falls (Skoyles 2006).

- An imperfect upright stance causes high energy consumption. It has clearly been demonstrated that an erect locomotion performed by quadrupedal primates is highly energy consuming (e.g., Lovejoy 1978; Wang 1999; Nakatsukasa et al. 2004). This has to be taken into account as an effective selective pressure against an erection of the body for locomotion. Here, it has to be kept in mind that an optimised modern human bipedality 
was still far from achieved, and after millions of years of selection, "the net costs of running and walking in humans... are not remarkable for an animal of its size" (Rubenson et al. 2007).

- A specific joint morphology found in fossil primates may be attributed to pronograde or orthograde postures or locomotion. Whenever a quadruped ancestor started to stand and to walk upright, this implies that the joints were subjected to new and different stresses. Adaptation started with the new positional and locomotor behaviour.

- Hydrostatic problems with several severe biological consequences (see below).

To put it in other words "Whatever one may think of it, the upright posture does not offer sufficient advantages for it to have persisted according to the classic criteria of natural selection" (Deloison 2004). However, as our sheer existence shows, "sufficient advantages" must have existed, and our ancestors were definitely able to fulfil the functional requirements of their environment and eventually acquired an erect locomotion. The main research problem in this context is to find out whether our current knowledge is able to explain this discrepancy convincingly.

Did our ancestors come down from the trees?

In most cases, when comparisons are drawn between extant primates and our putative ancestors, African apes, i.e., chimpanzees, pygmy chimpanzees (bonobos), and gorillas, are chosen as model (see below). Also, olive baboons and geladas have been used in order to draw analogies between extant quadrupedal primates and our ancestors. Sometimes, one may read, expressively or implicitly, at which time or why monkeys or apes gave up their lives in the trees in order to start a bipedal terrestrial way of living. However, neither any of the African apes nor any other quadrupedal primate model referred to above is an exclusively arboreal creature. In contrast, they are all often met on the ground, being well adapted to both environments, or they are, such as the gelada, fully terrestrial.

Investigating Scandentia (treeshrews) and primates, Niemitz (2002) has shown that, besides arboreal species, semiterrestrial and terrestrial treeshrews and primates also occur. If the members of small taxonomic units (e.g., genera or subfamilies) are compared, as a rule, the heaviest members of each taxon are terrestrial. Over 63 shrew and primate taxa were included in a correlation of arboreality vs. terrestriality to body mass (Niemitz 2002, 2004). Two examples, the treeshrews and members of the guenons, may be mentioned: The lightest treeshrew (Ptilocercus lowii) is arboreal, weighing about $40 \mathrm{~g}$ (Martin 1984), while the heaviest one, Everett's treeshrew (Urogale everetti), weighs about $355 \mathrm{~g}$ and is terrestrial (Napier and Napier 1968). The lightest guenon, the Talapoin monkey (Miopithecus talapoin), weighs below $1.5 \mathrm{~kg}$ and is definitively arboreal, while the heaviest and one of the most terrestrial primates, the Patas monkey (Erythrocebus patas), reaches a bodyweight of about $13 \mathrm{~kg}$ in the male sex. The males of orang-utan, which may weigh up to $91 \mathrm{~kg}$ (Shumaker 2004), do not fit well to this general idea. But together with the above examples, the complete correlation suggests that ground dwelling was common in primates, along arboreal habits, since their evolution began more than $60 \mathrm{Ma}$ ago in the late Cretaceous.

\section{From Miocene to Pleistocene}

One of the earliest hominoids known is Proconsul, which lived some 20 to $16 \mathrm{Ma}$ ago in the early Miocene of Kenya and Uganda and "has been thought of as a good candidate for a generalized ancestor of all great apes and humans (Kelly and Pilbeam 1986; Pickford 1986; Walker and Teaford 1989)" (Jablonski and Chaplin 1993). According to Simons (1992), Proconsul "was probably broadly ancestral to modern great apes". Although it is, thus, not a direct ancestor, it may serve as an appropriate model for our Early Miocene forerunners. It inhabited paleoenvironments, ranging from tropical rain forests to open woodlands. Proconsul africanus, showing a "monkey-like skeleton" (Fleagle 1988) "was quadrupedal and probably arboreal" but does not show any characteristics for suspensory habits (same reference). In several locomotor aspects, Proconsul heseloni may resemble extant macaques ( $\mathrm{Li}$ et al. 2002), which is in agreement with Niemitz (2004). Proconsul nyanzae "resembles $P$. africanus in many general aspects of its skeleton", being obviously rather closely related, "but shows adaptations for more terrestrial locomotion" (Fleagle 1988; see also Rose 1997). All this has been supported recently by Nakatsukasa (2004), who points out that the genus "Proconsul lacks most of the postcranial specializations for suspensory positional behaviour which are observed in living apes (see Larson 1998)". Nothing is known about the locomotor abilities of a third species, described as Proconsul major, but according to the size of the few teeth that have been found, it is definitely the heaviest member of the genus, with an estimated bodyweight of about $50 \mathrm{~kg}$. For this reason, it would rather not have been more tree dwelling than P. nyanzae, but more probably, it was at least as terrestrial as this latter species, the members of which weigh only about half as much.

The functional anatomy of about 20-Ma-old Morotopithecus from Uganda indicates "features of modern ape locomotion, reflecting climbing and/or suspensory activity" (Nakatsukasa 2004, see also MacLatchy et al. 2000). However, this fossil genus is even more derived than the gibbons (Hylobates; Young and MacLatchy 2004) and for this reason, cannot be a stepping-stone in the evolution of human bipedalism. 
Nacholapithecus, a further early hominoid from the early middle Miocene of northern Kenya (Nakatsukasa et al. 2000), is one of the most complete hominoid skeletons ever found (Ishida et al. 2004). Quite a number of postcranial anatomical traits of this hardly 18 or up to $22 \mathrm{~kg}$ weighing hominoid were discussed comprehensively by Nakatsukasa (2004). The axial skeleton, as well as functional limb anatomy, "suggest that Nacholapithecus with arboreal climbing abilities (Sénut et al. 2004) engaged in orthograde behaviours (e.g., vertical climbing, hoisting, bridging) more frequently than did Proconsul" (Nakatsukasa 2004). Although less well documented by fossil remains, another hominoid of about the same age, Kenyapithecus africanus was suggested to have shown scansorial activities combined with a forelimb-dominated positional repertoire and with a considerable terrestrial component (McCrossin et al. 1998).

In contrast to Proconsul, and especially to Nacholapithecus, Pierolapithecus catalaunicus, a fossil from the Middle Miocene from Spain being some 12.5 to $13 \mathrm{Ma}$ old and "probably close to the last common ancestor of great apes and humans" (Moyà-Solà et al. 2004), has a rather primitive hand, which is more similar to that of man than to extant apes. According to the same authors, the morphology of the Pierolapithecus hand indicates a considerable portion of palmigrade quadrupedalism rather than vertical climbing or suspension, and suggests that vertical climbing may be an "original modern ape adaptation". Although the interpretation of Pierolapithecus is still a matter of debate, Schrenk (2008) stated that the combination of its robust lumbar spine in this fossil primate with the abovementioned features was essential for the ancestors of later hominids. Stated with some prudence, all this could perhaps make it a suitable prototype for a later hominid branch in primate phylogeny.

According to Stauffer et al. (2001), molecular phylogeny suggests that the lineages leading to extant gorillas on the one hand and to humans on the other, started to diverge about $6.4 \pm 1.5 \mathrm{Ma}$ ago, while the bifurcation of the human and chimpanzee lineages may be dated about $5.4 \pm 1.1 \mathrm{Ma}$ bp. This agrees at least roughly with three rather recent paleontological discoveries, which are all claimed to belong to this phase of human evolution. The oldest is Sahelanthropus tchadensis and has been redated recently between 6.5 and 7.4 Ma (Brunet et al. 2005). Its authors (Brunet et al. 2004) state: "The new hominid is probably temporally close to the common ancestor of chimpanzees and humans but displays a unique combination of primitive and derived characters that clearly shows a close relationship to later hominids rather than with chimpanzees or gorilla", adding (2005) that supplementing findings "confirm the morphological differences between $S$. tchadensis and African apes". Zollikofer et al. (2005) suggest: "Analysis of the basicranium further indicates that $S$. tchadensis might have been an upright biped, suggesting that bipedalism was present in the earliest known hominids, and probably arose soon after the divergence of the chimpanzee and human lineages." But they qualify: "However, postcranial evidence will be necessary to test more rigorously the hypothesis that S. tchadensis... was a biped". According to genetic evidence, the human-chimpanzee speciation was estimated, after a rather long genetic exchange between the two lineages, to have occurred only <5.4 Ma ago (Patterson et al. 2006). Especially, as their results have been contested (Wakeley 2008; Patterson et al. 2008), a reconciliation of paleontological and genetic estimations has still to be achieved.

Orrorin tugenensis was dated to be approximately $6 \mathrm{Ma}$ old (Fig. 1; Sénut et al. 2001; contra Patterson et al. 2006, cf. above). With respect to locomotor adaptations, Sénut (2003) notes: "The position of the femoral head, the morphology of the femoral neck, the presence of a groove for the $M$. obturator externus and the cortical deposits on the femoral neck suggest that this hominid was a biped. Its traits are also closer to those of later Homo than of Australopithecines in the position of the lesser trochanter, the morphology of the femoral neck and the proximal shaft. However, the humerus clearly resembles those of Australopithecines and suggests climbing adaptations" (see also Pickford et al. 2002). This notion has recently been qualified by a morphological study contradicting Sénut and at the same time supporting her interpretation, "indicating that $O$. tugenensis was bipedal but is not more closely related to Homo than to Australopithecus" (Richmond and Jungers 2008).

Ardipithecus ramidus kadabba fossils were recovered from strata of the Middle Awash area of Ethiopia that date, according to paleontological methods, "to 5.2-5.8 Ma and are associated with a wooded paleoenvironment. These Late Miocene fossils... represent the earliest definitive evidence of the hominid clade" (Haile-Selassie 2001). Postcranial remains consisting of fragmentary humerus and ulna, as well as few hand and foot phalanges, have not been interpreted yet with respect to locomotion and show a mosaic of ape and hominid characters.

All this indicates that the posture and locomotion of the first hominoid ancestors of human beings were probably neither specialised for arboreal nor for terrestrial posture and locomotion. When becoming definitive bipeds, at the latest, however, they started to reduce the arboreal portion of their lives to varying percentages in different species (Niemitz 2004). Gebo (1996) concluded from his comparative anatomical studies that our ancestor was "quite capable as a climber" and yet, "...hominid bipedalism simply continues the terrestrial travelling trend evident in African apes". This is in general agreement with Hunt's interpretation of Australopithecus afarensis (1998), stating terrestrial and arboreal functions. Stern (2000), resuming decades of experience, noted: “... ever increasing numbers 
Fig. 1 Phyletic diagram of apes and Homo comprising the last $20 \mathrm{Ma}$, with several fossils that appear in the text (changed after Sénut 2003). To the author's conviction, only the semiterrestrial ancestors of the human lineage are older than indicated here (see text)

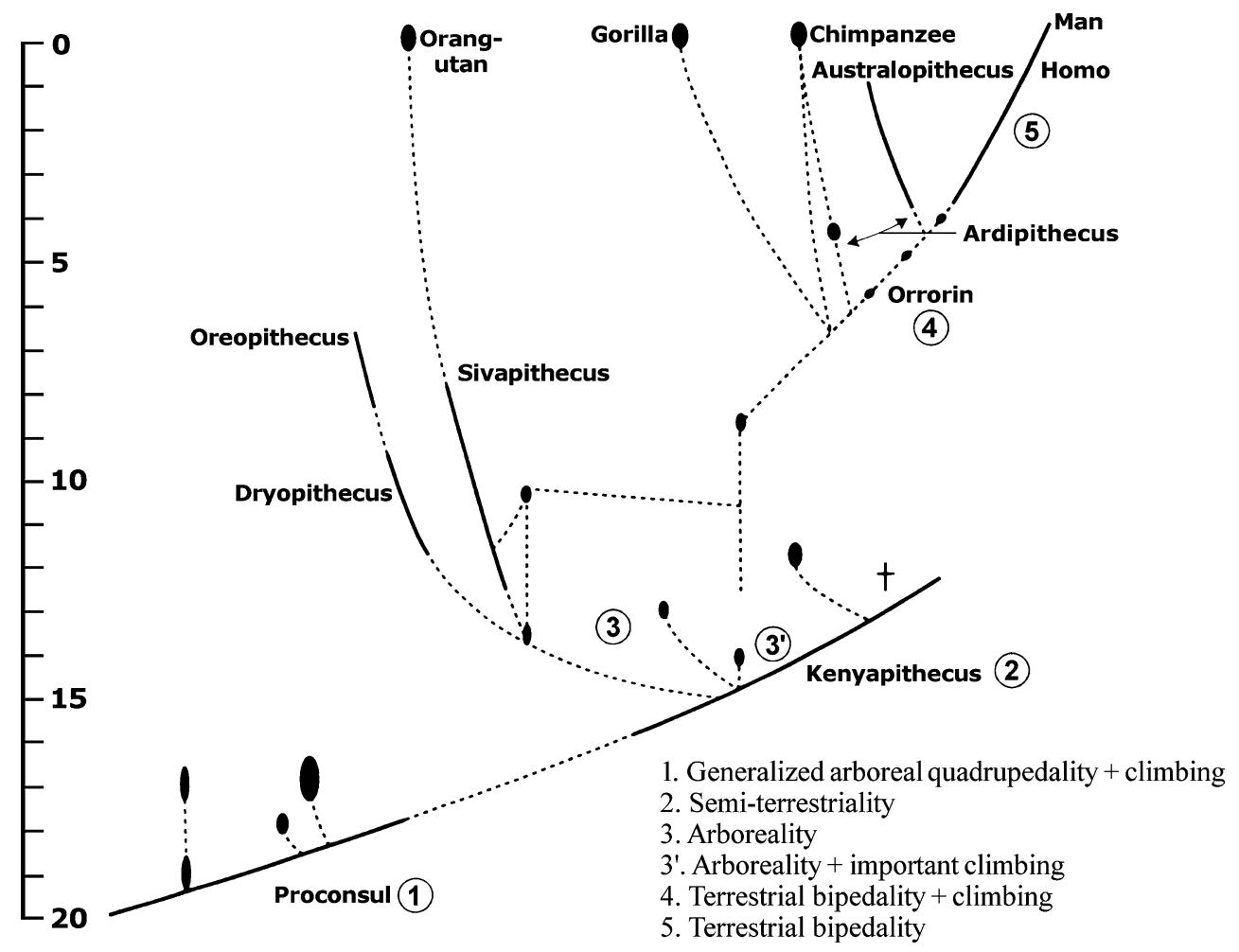

of anthropologists are accepting the arboreal behavior as an adaptively significant component of early australopithecine behavior... I was never as certain about the nature of $A$. afarensis bipedalism as I was about its retained adaptations for movement in the trees. I am no more or less certain now." As later fossils of Australopithecus and Homo are bipedal as well, they are considered elsewhere in the text for various reasons given there.

Before entering the next section, it has to be stated that knuckle-walking has never been explicitly considered to trigger or to cause bipedalism in a former quadrupedal primate. "This term should never be employed as a vague 'stage' of evolution, but used only in its original sense, as introduced by Tuttle (1967) as a descriptor of the characteristic locomotion of the African apes.... 'knucklewalking' is no more than the consequence of shortness of the digital flexors in a large mammal adapted primarily to climbing" (Preuschoft 2004). That is why it may be misleading in the context of the other hypotheses discussed here and shall be dealt with only briefly. Richmond et al. (2001; cf. also Richmond and Strait 2000a, b) stated: "the functional significance of characteristics of the shoulder and arm, elbow, wrist and hand shared by African apes and humans, including their fossil relatives, most strongly supports the Knuckle-Walking Hypothesis, which reconstructs the ancestor as being adapted to knuckle-walking and arboreal climbing" (the latter term not being specified by the authors with respect to behavioural aspects or stresses). This opinion of Richmond and coauthors pro- voked harsh contradictions, firstly on methodological grounds relating to the mathematical methods applied, as well as on the question, how to read the results phylogenetically (Dainton 2001) and secondly for reasons of functional anatomy (Lovejoy et al. 2001). As the aspect of knuckle-walking in our biohistory, although being central in several respects, is not a hypothesis in itself, it was only skimmed in this context as justified above.

\section{Evolutionary hypotheses for the evolution of habitual bipedalism and selective factors}

Today, the evolutionary acquisition of a bipedal posture and locomotion is placed into a rather forested habitat (e.g., WoldeGabriel et al. 2001; Sénut and Pickford 2004). Former hypotheses, placing this process into a savannah environment, are only discussed briefly, if they have either largely determined the discussion for a long period of time, or if some of their aspects are of continuing importance within the discussion of more recent hypotheses.

The Watching Out Hypothesis In 1959, Dart suggested that the visual advantage of being able to survey the surrounding might have favoured the adoption of a human erect posture. Rose (1976) took the behaviour of free-ranging baboons as a nonhuman model for our quadruped ancestors. Besides feeding posture (see below), he argued that baboons may sometimes stand up in order to watch out for 
various reasons including for dangerous predators such as hyenas or leopards. However, in a later study on bipedal behaviour of habituated chimpanzees (Hunt 1994), scanning the environment was recorded only twice out of 97 bipedal events, which is certainly insufficient to support the Watching Out Hypothesis. Including baboons, the same author stated: "Chimpanzees stood bipedally more often than baboons ( $0.3 \%$ versus never)" (Hunt 1996).

The Freeing of the Hands Hypothesis The second hypothesis to be discussed here goes even further back in time and is based on thoughts Charles Darwin wrote down in his Descent of Man (1871). When the fossil documentation of our past and the knowledge about the behaviour of monkeys and apes were still poor, Hewes (1961) noted: "A long list of names can be cited for the notion that 'freeing of the hands' for tool-using, weapon-handling, food-gathering, and self-defense was the main cause of hominid bipedalism (Darwin 1871; Haeckel 1900; Carter 1953; Hill 1954; Shapiro 1956; Washburn 1959: 24; Oakley 1960: 322)." This hypothesis has received widespread acceptance and was to be found in scientific as well as in popular literature (Ardey 1961). But, Hewes (1961, p. 694) also stated that all primates-including humans-do not assume bipedal postures for manipulation (see Carrying Food Hypothesis). Thus, while food transport may be considered as one of the possible contributing factors, the behaviour of man and of all nonhuman primate models indicates that manipulation is neither a trigger nor a promoter of standing or walking upright. Therefore, the freed hands were certainly used for quite a variety of purposes later in our biohistory.

The Throwing Hypothesis (Kirschmann 1999) The motor control and skill of throwing requires numerous anatomical adaptations, not only in the shoulder girdle and arm, but in the brain as well (e.g., Hore et al. 1995, 1999; Young 2003). In an unpublished manuscript, Kirschmann and Young write: "We suggest, that the specialization to use weapons... was a key adaptation for early hominids. The upright gait was developed as a trailing adaptation." Also, they declare the oldest stone tools of humankind to be 2.6 Ma old, while the first indications for an upright walk have been shown to be approximately 6 Ma old (Richmond and Jungers 2008). Since this is an unbridgeable time span of more than $3 \mathrm{Ma}$, the Throwing Hypothesis may contribute to the issue of human evolution elsewhere but not with respect to human bipedalism. Also, Dunsworth et al. (2003) found that the evolution of throwing "... possibly occurred with the emergence of Homo erectus...".

We know today that hominin orthograde locomotion evolved at least almost two if not several million years before tool production and before an accelerated brain growth is documented by hominin fossils. While the acquisition of upright locomotion is suggested to extend between at least 4.2 and about $6 \mathrm{Ma}$ back in time (e.g., Pickford et al. 2002), intensified and elaborated tool use beyond the chimpanzee scale appeared only 2 or 2.5 Ma before present (Semaw et al. 1997). The absence of evidence in the fossil record for tool use does, indeed, not necessarily mean the evidence for absence. But chimpanzees, as an extant model, use decayable materials such as wood as well as stone (e.g., Boesch 1999), and it seems most unlikely to the present author that, for at least $1.8 \mathrm{Ma}$, our ancestors selected decayable materials for their first tools exclusively.

The Infant Carrying Hypothesis Several hypotheses with relation to bipedal transport of loads were published at different times, each of them stressing other causes or parameters. The belief that women might have carried their babies was discussed by Etkin (1954), who argued that an upright locomotion in a hunting society might have been more effective if the females stood up and walked bipedally carrying their offspring on their waists. Also, Washburn (1967) stated the opinion that carrying babies might have elicited bipedal locomotion.

From their observations of infant carrying in savannah baboons of the Amboseli National Park, Kenya, Altman and Samuels (1992) calculated that infant transport by the mother consumes an approximate average of almost $350 \mathrm{~kJ} / \mathrm{day}$. However, for several behavioural reasons (necessary detours for picking the baby up, etc.), an almost double average value of $670 \mathrm{~kJ} /$ day has to be estimated. Only recently, Etkin's child-carrying hypothesis was tested in human beings quantifying the energy expended by measuring $\mathrm{O}_{2}$ consumption (Watson et al. 2008). These authors found that "...asymmetrical weights, such as a mannequin carried on the hip... are more energetically costly... and are...the most metabolically expensive methods of carrying". WallScheffler et al. (2007) calculated that "the burden of carrying an infant in one's arms... seems to have the potential to be a greater energetic burden even than lactation". They found that, after bipedalism had been established, tool use like that of a sling could reduce the caloric energy needed for passive child transport significantly.

Only as a matter of completeness, it may be added here that the energetic costs of carrying an infant has not been calculated yet for any ape. Erect bipedal infant transport seems to happen only when wading (Fig. 4e), although rare special situations of upright infant carrying on the dry land cannot be precluded. As "all Old World monkeys (Cercopithecidae), e.g. baboons, have solved the problem of an easy, fast and safe transport of their infants in an optimal fashion" (Fig. 2; Niemitz 2007), an evolutionary invention of a new, specifically human way of carrying little children was completely unnecessary, and after the calculations presented here, the Infant Carrying 


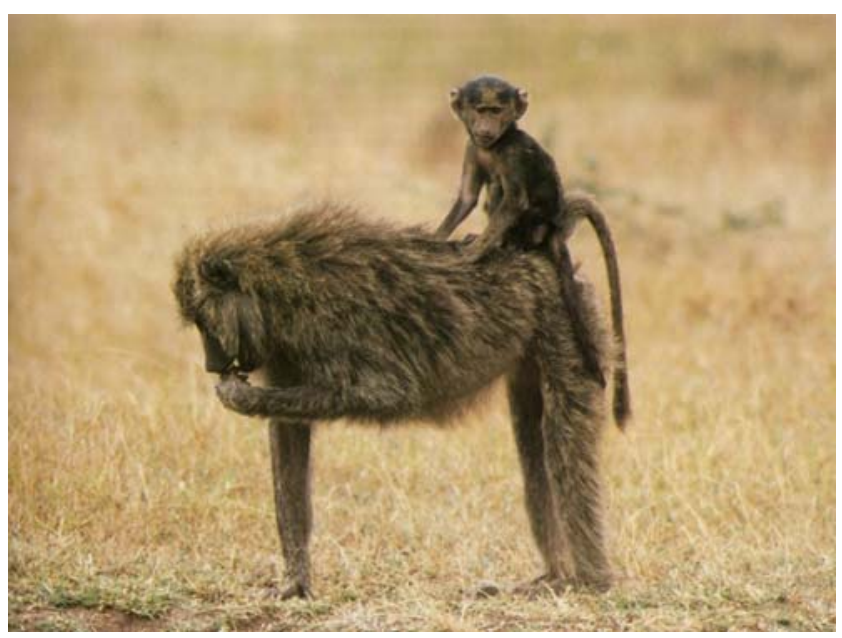

Fig. 2 Baboon mother (Papio anubis) with infant riding on her back. In case of danger, the female baboon can escape with similar velocity as if without a riding offspring. Also note the limb proportions and the horizontal spine (cf. text)

Hypothesis for the evolution of an upright posture and gait can be regarded as refuted.

The Reaching for Food Hypothesis Jolly (1970) favoured a more postural hypothesis for the evolution of early bipedalism suggesting that our ancestors, being placed in a savannah scenario, were forced to pick mainly high growing ears of grass or other kinds of high growing food. Rose (1976) presented a variety of triggers for baboons to assume erect postures. The most important ones to assume upright postures were fresh sprouts or inviting buds on a high bush. Wrangham (1980), observing gelada baboons (Theropithecus gelada), noted that they would sometimes move bipedally in a somewhat squatting position when picking seeds and other small food items from the ground. However, distances longer than $1 \mathrm{~m}$ were always covered in a quadrupedal manner. Therefore, these latter observations cannot serve as explanation neither for habitual upright postures nor for bipedal walking locomotion.

However, recording the behaviour of habituated wild chimpanzees for about $700 \mathrm{~h}$, Hunt (1996) found that "eighty per cent of chimpanzee bipedalism was during feeding; $86 \%$ of all bipedal activity arboreally and $70 \%$ terrestrially, and an overwhelming percentage of these bouts were postural (95\%)". Only once, he observed a chimpanzee moving bipedally (Hunt 1994, 1996), describing it as "short distance within-site shuffling" and elsewhere, as "...shifting one contact point, while minutely displacing the body's center of gravity..." (1994). In contrast, bipedal walking in the context of feeding behaviour was never observed. Yet, Stern (2000) refers to Rose $(1984,1991)$ and Hunt $(1994,1998)$ resuming: "Along with others, I believe the bipedal adaptation first arose to improve access to food sources close to the ground, movement between such sources, or both."
In such a situation of harvesting food, bipedality is often assisted by pulling or support of the upper extremity (Wrangham 1980; Hunt 1994). Besides adaptations for standing up, reaching for high food often and repeatedly may also contribute to the evolutionary acquisition of greater excursions in the shoulder joint: "The food gathering function of chimpanzee bipedalism suggests that hominid bipedalism may have evolved in conjunction with arm-hinging as a specialized feeding adaptation that allowed for efficient harvesting of fruits among openforest-woodland trees" (Hunt 1994). This notion can be reconciled in certain aspects with the hypotheses of food carrying, canopy scrambling, and wading (see below).

The Carrying Food or Provisioning Hypothesis According to the title of his article "Food transport and the origin of hominoid bipedalism", Hewes (1961) notes: "My thesis is that the arms and hands were needed for something other that locomotion: the carrying of food, and that only a bipedal gait could permit them to fulfill this need with real efficiency.... Köhler mentions that his chimpanzees walked upright when their hands were full (with food, CN) (1959:278-79)... Leakey (1959) observed such behaviour in his pet baboon when carrying ears of maize". Hewes presents a drawing of a macaque carrying some bulky food bipedally, and I remember a photograph of Macaca fuscata on Koshima Island carrying a sweet potato in this fashion. However, to the knowledge of this author, wild great apes rather avoid bipedal locomotion when transporting food. Captive gorillas and chimpanzees may even transport up to four food items in both hands, one foot, and with their mouth simultaneously in a quadrupedal fashion (own observation).

Nevertheless, bipedal food carrying is certainly performed sometimes and may similarly have occurred in our ancestors. Although bipedalism is not often performed in the context of food carrying, it may perhaps remain a possible contributing factor to the evolution of habitual upright bipedalism. If an erect posture is accepted as a behavioural stage before the evolution of the upright walk, feeding adaptations may well have contributed to the emergence of later modern human bipedalism. However, further functional factors were necessary to establish the habitual erect posture and especially, habitual upright walking behaviour.

In an early article, Lovejoy (1981) sketches a behavioural sequence: "It is likely that the need to carry significant amounts of food was a strong selective factor in favour of primitive material culture. Although it is not a significant shift from primitive tools of the type chimpanzees use today, such as 'termite sticks'... to simple and readily available natural articles that could be used to enhance carrying ability, it is a significant shift from such primitive and occasional tool use to the stone tools of basal Pleistocene." He argues that provisioning was necessary, 
being one feature of the intensified parental care of early human antecedents increasing the survival rate of infants. According to this idea, male provisioning mediates between the evolution of bipedalism, tool-use and human monogamy (Lovejoy 1981).

The Display Hypothesis Although this hypothesis is one of the savannah theories, it shall be discussed, because some of their reasoning might also fit into a more wooded habitat. From a current perspective, this hypothesis is pleasant and somewhat disturbing at the same time: "We propose that the bipedal displays of pre-hominids led to resolution of intragroup conflict almost exclusively by ritual and gesture and only very rarely deteriorated into injurious attacks." The attractive aspect is that bipedal threat displays are assumed to combine the evolution of bipedalism with the acquisition of a conflict-solving signal. On the other hand, the disturbing fact is that, it can definitely not be decided how often a bipedal display may have led to either an appeasement or to an open fight. Today, speculations of this kind on the putative communication of our ancestors can certainly not serve as a fundament for any evolutionary hypothesis.

One of the central elements of the hypothesis is the transmission of females from group to group: "We propose that female transmission ultimately led to the successful establishment of habitual terrestrial bipedalism..." (Jablonski and Chaplin 1993). On the one hand, these authors point out: "It can be envisioned that the performance of unique bipedal displays, occasionally resulted, by dint of their sheer novelty, in the winning of encounters between males from different groups by their surprising effect" (my italics). They continue: "The offspring... may have stood up more and thus achieved higher status by this novel behaviour". On the other hand, however, the authors do not consider how a novelty may maintain a surprising longterm effect, even if it is repeated innumerable times over many generations in order to establish a habitual bipedal posture and gait within the population.

With the exception of a short yet not discussed remark on juvenile play, not a single other trigger for an increase of bipedal behaviour in quadrupedal forerunners is discussed. By focussing exclusively on their own explanation, Jablonski and Chaplin were unable to discover or to weigh the amount of a possible contribution of display behaviour to the evolution of bipedalism. Display behaviour is per definition associated with short behavioural episodes. With regard to the behaviour of wild free-ranging chimpanzees, Hunt (1996) found that "social display (1\%)" was "rare". Therefore, this hypothesis does not seem suitable to explain why displaying individuals - and especially the other members of their group - should have remained upright after the actual social situation had been solved.
The Orthograde Scrambling Hypothesis Studying female orang-utans, Sugardjito and van Hooff (1986) as well as Cant (1987) point out that, most of the time, they observed a fourhanded scrambling fashion for travelling in the canopy of the trees - not clearly specified as orthograde or pronograde in both sources - combined with brachiation and tree swaying, adding that quadrupedal walking and vertical climbing occurs much less often. The Orthograde Scrambling Hypothesis was first presented to a Congress of the Werner Reimers Stiftung and Forschungsinstitut Senckenberg in 1999 (Crompton et al. 2003) and appeared again in a revisited and supplemented new version (Thorpe et al. 2007a). Recently, it was comprehensively discussed in a somewhat different context by Crompton et al. (2008). In quite a number of statements and arguments, it repeats the considerations of Gebo (1996), who had concluded: "It is not climbing but traveling locomotion that best divides the living apes into discrete groups... Orangutans travel via scrambling, brachiation, and tree swaying. Among orangutans, only males use the ground for traveling over long distances, and that only occasionally (Galdikas 1979, 1988; Rodman 1984)". As its name implies, the Orthograde Scrambling Hypothesis points out, more than it has been done by Gebo, that orang-utans often adopt a more or less upright posture, especially when suspension is needed on rather thin branches in order to secure the individuals from falling down. Its advocates argue that this upright travelling locomotion of orang-utans in the crown of high trees represents an ancestral behaviour which has been retained in later hominin bipedalism. Thorpe et al. (2007b) observed that orang-utans extend hip and knee joints under circumstances that would be preadaptive to the fully extended hominin knees and hip when walking upright. The authors find that, "during the Miocene... orangutan ancestors became more specialized, and restricted to, shrinking closed canopy forest that could be traversed at canopy level". Gebo (1996) underlines this notion of locomotor specialisation by comparing the adaptations of extant orang-utans to sloths, because of the far-reaching anatomical alterations of the upper extremity and especially of the hand of Pongo.

The specialisations of extant orang-utans are manifold and not at all restricted to locomotor features, but also to marked ecological and behavioural differences from African apes. Some of them are mentioned by Thorpe et al. (2007a), but include also, e.g., enamel structures of the teeth and many further traits (cf. Niemitz 2002, 2004). It has been recognised from molecular data (e.g. Friday 1992) as well as from multivariate functional biometry that Pongo clusters, in many respects, much more closely and more easily with gibbons than with African apes: As early as in 1979, based on 23 dimensional data of total body proportions, Oxnard (1979) demonstrated this close functional and phyletic relationship (see also Oxnard 1983). The 
bifurcation of the orang-utan clade from the chimpanzee, gorilla, and human branch is commonly dated between some $11.3 \pm 1.3 \mathrm{Ma}$ ago (Stauffer et al. 2001) and about $15 \mathrm{Ma}$ (Fig. 1) resulting in, roughly, between 20 and almost $30 \mathrm{Ma}$ of separate evolution in both the orang-utan and the human branch (e.g., Begun 2003; Moyà-Solà et al. 2004). This bears a variety of obstacles for the hypothesis discussed here, because the danger to misinterpret possible autapomorphic features of the specialised orang-utans after their long genetic separation from the African apes.

In their predominantly superb anatomical review, Crompton et al. (2008) state: "Only one living great ape, the orang-utan, has been observed to engage in suspensory quadrupedalism: neither the panins nor the gorillines exhibit this behaviour (Thorpe and Crompton 2006). The absence of such gait in panins and gorillines might, however, be a simple statistical consequence of much more exclusive arboreality (my emphasis) in Pongo". The locomotor similarities of orang-utans to man stated above, together with their relative phylogenetic distance to Homo in relation to the distance between Homo and the panins/gorillines, raise further questions about the origin of the similarities described.

Also, both opinions, the one by Thorpe and colleagues on the one hand and the second by Gebo on the other, have much in common, although the former authors contradict the latter one decidedly. To mention only one example, both stress the appearance of a heel strike - which is also a feature of modern human walking - by the orang-utan while walking but interpret its function differently. While Gebo (1996), citing Cant (1987), calculated that "... we can assume that heelstrike plantigrady is rare in the arboreal locomotion in orangutans", Crompton et al. (2008) emphasise the occurrence of the heel-strike in the orang-utan and discuss this phenomenon together with "the highly extended hip and knee in voluntary bipedalism of orang-utans" (p. 506). The heelstrike shown in their photograph, however, occurs with flexed hip and extended knee, while the "clearly double humped curves in $25 \%$ of cases" exemplified by a graph, shows a clearly unimodal curve with only one hump.

With reference to their comprehensive observations in the field, Thorpe et al. (2007b) point out: "Bipedalism was strongly associated with locomotion on multiple supports and with locomotion on the smallest support diameters" and simultaneous suspension with the forelimbs going along with an orthograde posture. This is in agreement with observations of Hunt in chimpanzees (Hunt 1996). Yet, Thorpe and coauthors (2007a) derive a later biped human locomotor behaviour from a kind of terminal branch feeding: "The advantage of hand-assisted bipedality is that the hand assistance ensures maximum safety while the bipedalism enables an unloaded hand to reach out for feeding... in the peripheral branches, where the majority of the preferred foods are situated". While the lighter gibbons have optimised brachiating suspension for locomotion and terminal branch feeding, according to this proposition, the heavier orang-utans may have evolved bipedalism combined with an orthograde suspension for the same purposes. Nevertheless, this orthograde posture of orang-utans while foraging with suspension stress in the upper limb is paralleled - if evolved separately or not-by the feeding behaviour of chimpanzees discussed above (Hunt 1996).

This common specialisation for crown dwelling and terminal branch feeding behaviour may underline the extraordinarily similar morphometrics of orang-utans and gibbons stated above. Their rather minor differences may mainly be associated with their body mass, substrate use for locomotion, and corresponding joint mobility (cf. Isler 2002; Isler and Thorpe 2003) and thus, ultimately, for their differences in body weight. Among mammals, orang-utans belong to the heaviest canopy dwellers of the world. They are an extraordinary exception requiring extraordinary specialisations.

The Scavenging Hypothesis Two publications, which appeared in the same year, postulate regular scavenging of our ancestors as important for human evolution (Eiseley 1953; Bartholomew and Birdsell 1953). From time to time, carrion robbery was proposed as a central factor of food acquisition at the early stages of human evolution. Some 40 years later, Blumenshine and Cavallo (1992) revived this theory adding a number of substantiations. However, the updated Scavenging Hypothesis was associated with the definitely bipedal australopithecines and separated from the evolution of an upright posture and locomotion. Thus, the hypothesis of carrion robbers is no longer considered in relation to the evolution of upright hominids but refers to later times in our biohistory. Nevertheless, this new version is relevant in so far as its authors located this hypothesis in a new scenario. They concluded that fresh carrion as an important food resource was available with greatest probability in gallery forests along the rivers and streams: "The earliest hominids may have come across defleshed kills while foraging for plants in thin ribbons of riparian woodlands" (Blumenshine and Cavallo 1992). This remark is in agreement with the Amphibian Generalist Theory (see below).

The Aquatic Ancestor Hypothesis In his book on the specifically human evolution, Westenhöfer (1942) dedicated one short chapter to "The hypothetical aquatic life?" of prehuman and even preprimate mammals. In his title, he began the chapter with an interrogation mark and he concluded his reasoning with the careful notion: "Such, at the first glance, so improbable hypotheses are, of course, just meant to be stimulations, in which directions research might be done, like a detective, who pursues also the most improbable indication alongside others, which seem to be more promising." Later, the Aquatic Ancestor Hypothesis 
(AAH) was renamed as the so-called Aquatic Ape Theory or AAT (Morgan 1990).

To the author's conviction, the Aquatic Ape Theory, as described by Morgan (1990) did neither fulfil the criteria of a hypothesis nor of a theory. And, in fact, by that time, its author did not intend to postulate a hypothesis of her own: Instead, she listed analogies of features of savannah type mammals on the one hand and of aquatic mammals and man on the other, asking the scientific community for explanations other than a common aquatic ancestor of extant man. Nevertheless, it was a rewarding enterprise by Roede and colleagues to compile a volume of not less than 22 chapters, partly by renowned scientists, on the relationship of human ancestors to water (Roede et al. 1991). As an example for that volume, Preuschoft and Preuschoft (1991) presented a biomechanical study, which showed that humans are far too bad swimmers ever to have been derived from a swimming ape ancestor. More recently, Morgan (1997) has stressed more the littoral aspects of her ideas, approaching, to some extent, Niemitz's conclusions $(2000,2004)$. And indeed, in a weaker version, there are positive votes to be noted (e.g., Hrdy 1999). Groves and Cameron (2004) wrote: "... although the authors shy away from more speculative reconstructions in favor of phylogenetic scenarios, we insist that the AAH take its place in the battery of possible functional scenarios for hominin divergence".

The Thermoregulation Hypothesis Like in other hypotheses on the evolution of the erect posture, some of its basic ideas were thought and published a long time before the hypothesis itself was formulated. In 1967, Ward and Underwood had calculated the advantage of an upright stance with respect to the exposure to equatorial solar radiation. It lasted more than 15 years, until Wheeler (1984) wrote: “... it is proposed that hominid bipedality could have evolved as an adaptation to alleviate what is probably the single most stressing problem of open equatorial environments: heat gain from direct solar radiation". Hence, that author derives the evolution of human bipedality from only one single assumed cause.

Moreover, in all of his main articles (1984, 1985, 1990, 1991a, b), Wheeler expressly related this evolutionary development to a savannah scenario, which has been shown to refer to a later stage in already bipedal hominins. Also, applying simulation calculations, Chaplin et al. (1994) contradicted Wheeler concluding "that thermoregulatory considerations were not sufficient to overcome the difficult morphological transition from quadruped to committed biped". The reply of Wheeler (1994), although justifying some of his own results successfully, was not suitable to abolish the main difficulties to accept his hypothesis as a whole. Nevertheless, I consider his findings to be an important contribution to the understanding of later human evolution as a walker and runner.
The main question is not what made our ancestors stand up

All hypotheses discussed hitherto produced functional causes favouring the assumption of an upright posture. Each hypothesis presented only one single reason, why an orthograde posture or locomotion might bear a positive selective favour. But the ecological and behavioural setting for the very beginning of upright postures and locomotion was, certainly, much more complicated, and it is unlikely that there was only "one specific reason why bipedalism was selected for" (Harcourt-Smith 2007, p 1490). Also, "it appears likely that the skeletal alterations for bipedality would be under strong selection only by consistent, extended periods of upright walking and not by either occasional bipedality or upright posture" (Lovejoy 1981). Hence, all hypotheses hitherto discussed offer no explanation for the very decisive topic: The main question is not why our ancestors stood up for some reason and for longer durations than they had done before. It is of much greater importance why they remained upright afterwards, and why they started walking for a considerable span of time.

As an example, the appearance of some predator should no longer have reminded those transitional "bipeds-quadrupeds" to escape using all four limbs in a galloping manner: if this would still have been faster than a bipedal flight, full bipedalism would certainly never have evolved. The question a promising hypothesis must explain is which combination of selective pressures overcame the threshold, so that habitual standing upright and continuous bipedal walking started to pay off.

The "Amphibische Generalistentheorie" (Niemitz 2000, 2004, 2006, 2007) or shore dweller hypothesis postulates that several advantages may have favoured a wading behaviour selectively:

- On the shores, there is plenty of high quality food, which could be collected with very little investment. This is consistent with the fact that several authors claimed an increasing scarcity of food caused by the fragmentation of the forest during that time (e.g., Jablonski and Chaplin 1993).

- It can be collected there with high reliability throughout the year (e.g., Cowlishaw and Clutton-Brock 2001; Nikolai 2002).

- Submerged body parts are almost weightless and contribute almost nothing to the weight load onto the respective joint surfaces. If wading bipedally, the joints of the hind extremity could be relieved from some of the unphysiological pressure. If the water is deep enough, this refers also to the lower vertebral joints.

- Sometimes, water may offer sufficient viscosity and buoyancy to prevent an individual from falling if a step is placed less precisely. Knee-deep water is fairly 
sufficient to reduce possible injuries during the transitional phase when "balance abilities... evolved" (cf. Skoyles 2006; see below).

According to this hypothesis, the human clade derives from an ecologically nonspecialized ancestor that was opportunistic in its feeding habits. Also, "the immediate precursors to the very first hominins are likely to have been rather generalized hominoids (McHenry 2002)" (Harcourt-Smith 2007). This is consistent with the nonspecialized functional anatomy of human teeth and of the whole human intestinal tract, based on the old perception that evolutionary radiation is much more likely from a nonspecialist towards a more specialised ecological niche than the reverse. The teeth of hominids indicate that their antecedents have always been omnivorous (Blumenshine and Cavallo 1992). The utmost omnivorous habits of extant human beings can hardly be explained on the basis of an ancestor that would have been a specialist for a certain kind of food like such as seeds or leaves, etc. While teeth and intestinal tract in our closest relative genus Pan are adapted to a variety of food types (e.g., Fleagle 1988), they show specialisations in gorillas and orang-utans that were acquired during their own special evolution. Gorillas possess strong, large, and pointed teeth adapted to crush and shred hard plant material including wood and bamboo as well as a very spacious caecum (Napier and Napier 1968) and a specialised intestinal flora. Orang-utans show very specialised crenulated occlusal surfaces on their molar teeth (Fleagle 1988, Fig. 3b).

Moreover, our ancestor was also not specialized to any specific locomotor habits as it was a semiterrestrial ecological generalist. This is consistent with the reconstruction of McHenry (2002) of our human precursors. The arboreal adaptations were used for collecting different kinds of food during the day and for nesting at night, while the ground was used more for travelling, for collecting other kinds of food including resources rich in precious animal protein. Such a kind of semiterrestrial ancestor was also postulated by Sénut et al. (2001) noting "The postcranial evidence suggests that $O$. tugenensis was already adapted to habitual or perhaps even obligate bipedalism when on the ground, but it was also a good climber" (see also Sénut 2006).

Together with our gradually increasing knowledge on the geological developments during late Miocene of Africa, several fossil discoveries of the last decade indicate that the quadrupedal-bipedal transition took place in the huge areas of patchwork forest between the west and east coast of Africa with many thousand kilometres of shore lines along streams, lakes, and rivers (cf. Schrenk et al. 2004). Considering the size of this area, it seems possible that there was more than one "experimental" transitional species. Hence, in this kind of environment, Sahelanthropus, Ardipithecus, and likewise,
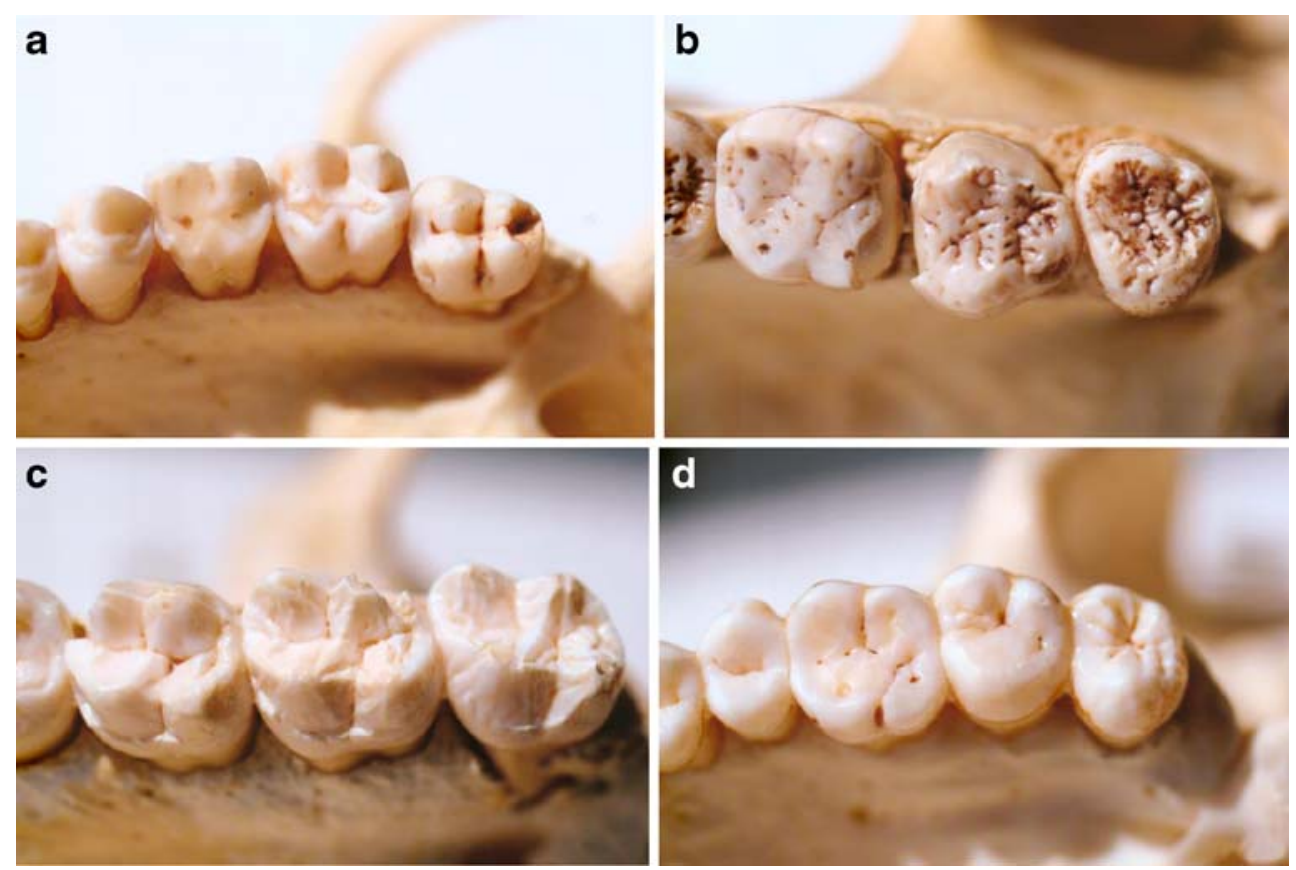

Fig. 3 The molar teeth of a macaque (a M. nemestrina) are suitable for processing a great variety of food. Those of orang-utan (b Pongo pygmaeus) or of gorilla (c G. gorilla) are rather derived and specialized showing enamel ridges in order to break plant fibers (b), or they are massive and pointed to shred hard plant materials like wood (c). Besides new evolutionary acquisitions, the teeth of human beings

(d H. sapiens) are much more conservative in many respects as they lack many specializations. No indications exist that these generalized functional features are secondary. It is much more likely that the basal anatomy of human teeth, like that of the intestinal tract, still resembles in several aspects that of an ancestral ecological generalist. The teeth of the macaque (a) may serve as a more or less appropriate model 
Orrorin could also be negotiated as potential "experimental stages" within the frame of this hypothesis (Schrenk, personal communication).

The fragmentation of the African forests and to the emergence of open plains in the period regarded here is undisputed and general knowledge. However, most of the above theories about the beginnings of bipedality associate the evolution towards an upright spine for posture and locomotion directly to this process: "Contemporary paleoanthropological opinion places the transition to hominid status in tropical park-savannah lands, where narrow forest environments extend along river-courses, flanked by grassy plains (Washburn and Howell 1960)" (Hewes 1961 p. 700), which is in agreement, e.g., with Jablonski and Chaplin (1993, see above), Thorpe et al. (2007b), and many other authors. For the first biped known, $O$. tugenensis, Sénut (2004, p. 377) noted a "predominance of impalas and colobine monkeys" indicating the combination of grass and forested area, and continued: “... the presence of carbonate oncoliths and concretions of algal or bacterial origin... suggest that Orrorin inhabited a forested environment on the fringe of a lake margin, where hot springs could be found." Thus, nowadays, early bipedality is related to an ancestor that "occupied a relatively humid environment" (Sénut and Pickford 2004; also Sénut 2006). Although disputed, according to its authors (Brunet et al. 2004), Sahelanthropus is another putative fossil hominin which is some 6.5 Ma old. They point out: "The fauna comprises vertebrates that are aquatic (fish, turtles, crocodiles) and amphibious (anthracotheriids, hippopotamids) but also species adapted to the gallery and islet forests (monkeys), wooded savanna (proboscideans, giraffids, suids, etc.) and grassland (bovids, tridactyl equids)".

In most of the sites where fossil hominids have been found and which are sufficiently comprehensive to allow conclusions about the fauna and flora, indications are found for a humid environment, if not immediate indications for shore dwelling. Australopithecus anamensis was described by Leakey et al. in 1995. Its species name is derived from the Turkana word "anam" (lake), because the hominid and accompanying remains did not only indicate a life on the shore, but also suggested food collected from the water, like shells crushed in a certain manner (Leakey, personal communication). The excavated collection from Ethiopia accompanying AL-288-1 A. afarensis "Lucy"-as well as many of the other more than 300 individuals of $A$. afarensis found so far - clearly indicate a life on the shore (Bearder 2000). This was also confirmed by Schrenk (2008), who pointed out that the behaviour of $A$. afarensis "aimed to maintain a close relationship to the broad habitats of the river shores". WoldeGabriel et al. (2001) noted with reference to the Afar-hominids: "... these earliest hominids derive from relatively wet and wooded environments". A third species of this genus is Australopithecus bahrelghazali, named after the "river of the gazelles" ("Bahr el Ghazal") according to the reconstruction of its way of living. It was found in a place which today is located amidst Sahara desert and was then a green river valley (Brunet et al. 2002).

Until recently, the teeth of the robust australopithecines (Paranthropus sp.) were unmistakeably interpreted as being most specialized for hard seeds and other resistant plant material. However, although only published as an abstract, new isotope analyses, combined with investigations on the occlusal morphology of the premolars and molar teeth, give new insights. They suggest that Paranthropus rather lived "as a member of a guild of hard-shelled invertebrate consumers in wetland and mesic ecosystems" (Shabel 2005). The food types suggested here are potamonautid crabs (e.g., gammarids) and achatinid molluscs, as they are preyed upon by the marsh mongoose (Atilax) and the clawless otter (Aonyx).

Even though the abovementioned species are thought to postdate the evolution of bipedalism, it is necessary to state that this habitat use was not only widespread, but even more important; shore use can be shown for all periods of time later. In the past, it was taken for granted that the former presence of shallow water at the location of an excavation site of a hominid fossil was a logical consequence, there, of the relatively high chances for fossilisation. In contrast, a dead body in the savannah is most likely to be chewed up by hyenas, and the last bony fragments are scattered by jackals and lost. The chances described to fossilise in a swamp or in a savannah are certainly correct and not contested. But as the many examples unambiguously show, the doubts or even objections against shore dwelling using the chances of fossilisation as an argument of almost absolute rank, are just not valid anymore and outdated.

\section{Water use in extant primates and selective pressures}

In analogy to the hypotheses discussed above, this leads us to the question whether there are any extant primates which may serve as models for fossil early apes on the fringe of bipedalism. For a start, it seems worthwhile to check how many of the living Old World primates do have an ecological or behavioural affinity to water, or in contrast, which ones have such an affinity to savannahs or other more open or dry habitats. A very comprehensive compilation is given by Rowe (1996), who lists 109 Old World monkey and ape species, also including man, his description being based on not less than 1,020 references. Listing all primates with entries such as "dry forest" or "semidesert", but also including "deciduous dry forest", "dry woodland savanna", or "savanna is used rarely", 25 monkey and ape species were found corresponding to $23 \%$ of the Old World primates. Doing the same with entries like "swamp", "gallery forest", "flooded forest", "mangrove", or "riverine 
species," not less than 40 species appeared, which corresponds to $37 \%$ of the haplorhine primate species contained in Rowe's book.

Adding the information given by the leading authorities of the respective primates in Macdonald's New Encyclopedia of Mammals (2001) as well as a number of further references, not less than 49 species of higher primates were labelled as, at least occasional, swamp, mangrove, or shore dwellers, etc. (Table 1). This does not only correspond by size order to almost half of the higher primates, but the list shows that all great ape species except for the mountain gorilla are reported to feed from water resources, either water plants or water animals (Table 1). Of course, in terms of evolution, their mere number does not offer hard evidence. Although not each swamp-dwelling monkey species will make considerable use of the aquatic portion of its habitat, the high percentage of the inhabited landscape, however, suggests that a humid habitat must well be taken into account for the ecological and evolutionary provenience of our ancestor.

The relation of the number of dry habitats mentioned against humid and wet habitats may be an easily comprehensible consequence of the well-known fact that dry habitats are, in general, much less rich in food resources than more humid ones. This was certainly so since the times when savannahs began to emerge as islets within a net of broad areas of green forests accompanying the water streams, with gallery forests along their shores. As several authors point out (e.g., Cowlishaw and Clutton-Brock 2001), the use of the reliable food supply on the shore and in shallow water by primates is also a strong selective factor today, ensuring their survival which might otherwise be endangered (Fig. 4). The Amphibian Generalist Theory also stresses the kinds of food higher primates, and especially, apes have been documented to collect in this habitat. Along with water plants such as large bulks of algae (Hanuman langur) and Nymphea roots (baboons, Toque macaques), fresh water shrimps, snails, and fish are the kinds of food that have been reported most. Ape species known to be predominantly vegetarian seem to easily gain a precious animal protein supplement to their vegetarian food by taking a quadrupedal walk on the shore (Fig. 5).

\section{Wading causes bipedal walking}

In most cases, a monkey or ape assumes an upright bipedal posture as soon as it ventures into the shallow water. This has been explained as a necessary consequence of the distribution of body mass in higher primates (Niemitz 2004, cf. Kimura et al. 1979; Kimura 1985; Demes et al. 1994). In contrast to all other hypotheses discussed above, wading behaviour, as proposed here, is the only behavioural pattern in which a primate is not only stimulated to stand up or to make one or two steps (e.g., harvesting food; see above). When foraging in the water, the monkey or ape is forced not only to stand up but to walk (Fig. 4).

\section{Locomotion and body proportions}

The Amphibian Generalist Theory proposes a quadrupedal nonspecialized ancestor, which is consistent with Hewes (1961, p. 705). While P. africanus has been interpreted as "monkey-like" and rather "arboreal" (Fleagle 1988), the fossil remains of $P$. nyanzae suggest a somewhat more terrestrial life (same reference). However, to choose a single Miocene species as an ancestor for much later humans would definitely be wrong, especially if the many and increasing number of species of later australopithecines is considered. Therefore, the genus Proconsul offers both arboreal and semiterrestrial adaptations, the Early Miocene being suitable for a later bipedal descendent.

In relation to the length of the spine, present-day human beings possess longer upper limbs than early Miocene apes like Proconsul. This may be interpreted as an early adaptation to a partly arboreal life and particularly, to vertical climbing - upwards in order to climb fruiting trees or to reach nesting sites at night and downwards for all terrestrial purposes (e.g., Fleagle et al. 1981; Niemitz 2004; cf. also the discussion of Nacholapithecus by Nakatsukasa 2004 in this article).

Except for the orang-utan terminal branch-feeding locomotion, which happens in a rather slow fashion, bipedality has always been combined with a terrestrial way of life. However, all terrestrial monkeys-as well as Proconsul without regard for its degree of terrestriality - have front and hind limbs of similar lengths. This shows that terrestrial quadrupedalism does not favour longer legs, which is in agreement with Witte et al. (1991). On the other hand, although the largely bipedal australopithecines still possess rather short hind limbs, the Amphibian Generalist Theory or Shore Dweller Hypothesis offers several functional, i.e., selective, factors for the evolutionary beginnings of longer hind extremities from the very start of upright locomotion and posture (c.f. Niemitz 2006, 2007). For some time, there must have been a trade-off, for longer bipedal wading hind extremities and relatively shorter ones for terrestrial quadrupedalism in combination with the possibility of a fast vertical escape up into the branches. The specific power of each of these selective factors is hitherto unknown. In any case, wading may offer advantages for longer legs that may well have contributed somehow in this process (Fig. 6).

However, an increase in body size may well have the same effect as long hind limbs, because a higher stature counteracts the unfavourable effects of buoyancy in a similar way as long legs do. In this context, it is startling that "the femur and humerus of Orrorin are 1.5 times larger 


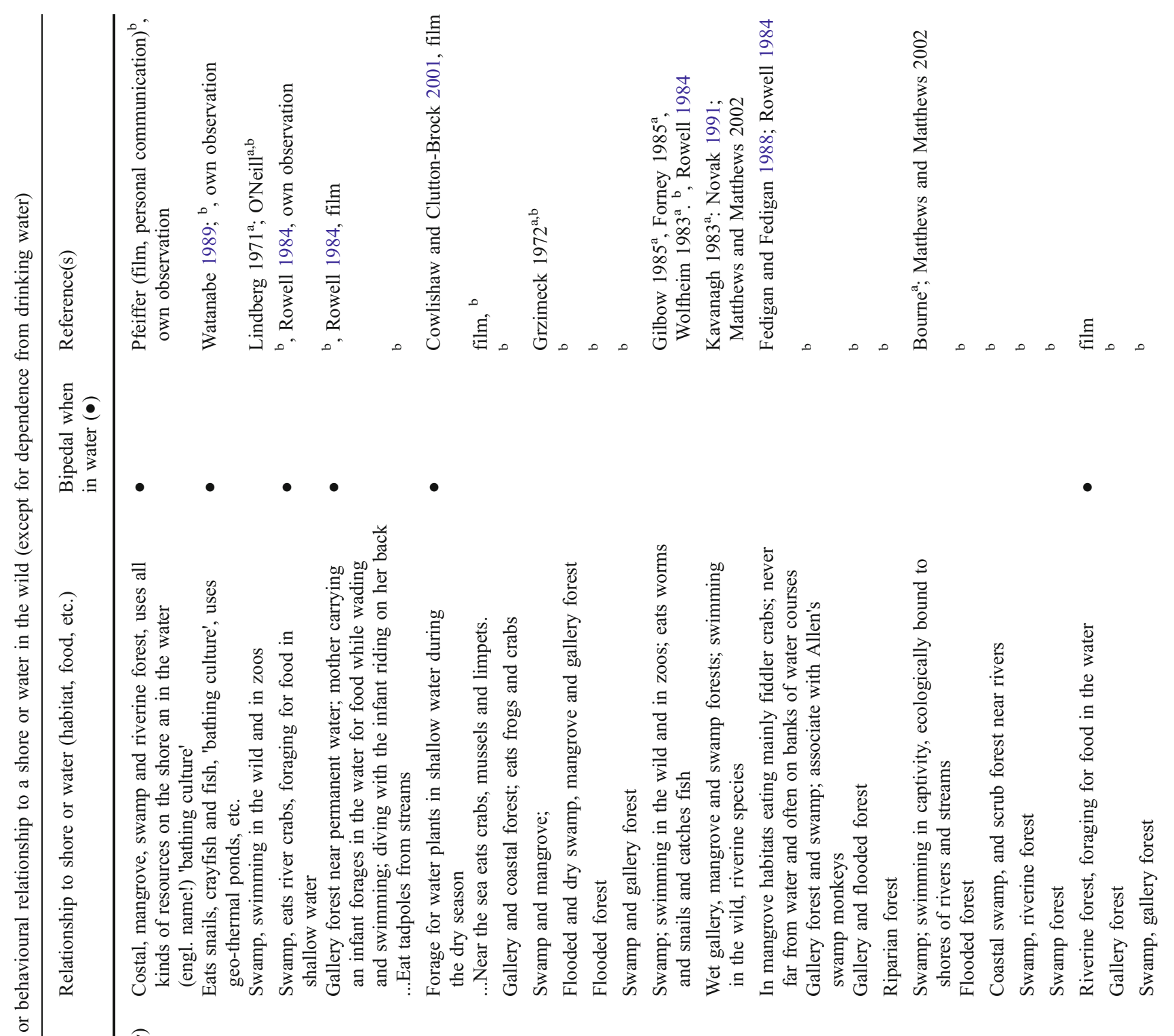



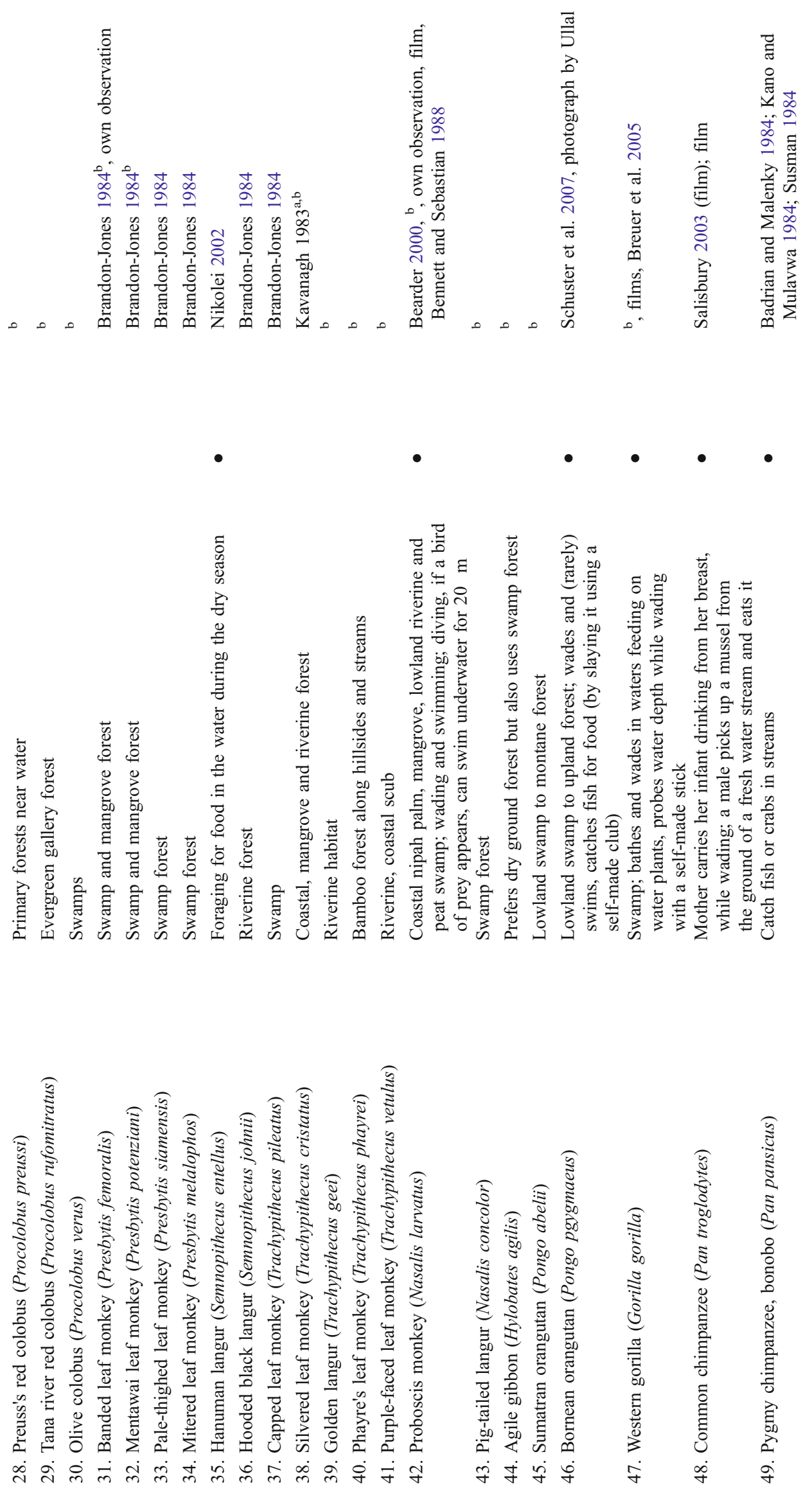

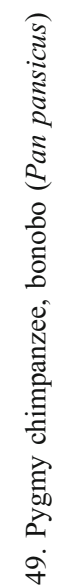

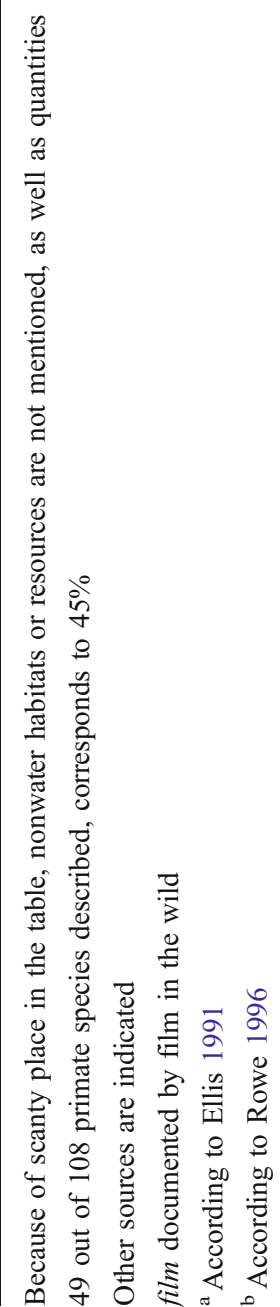




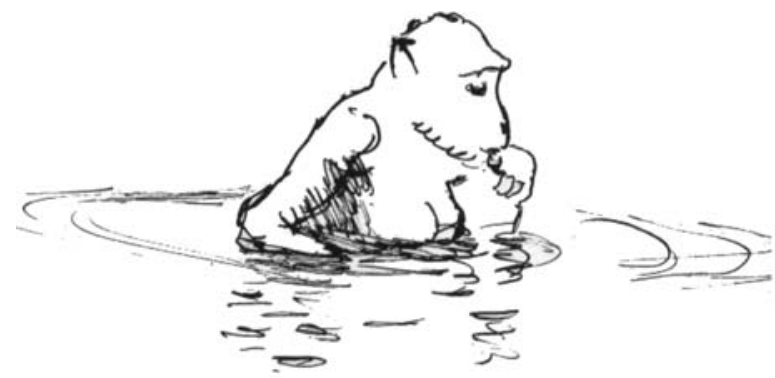

a

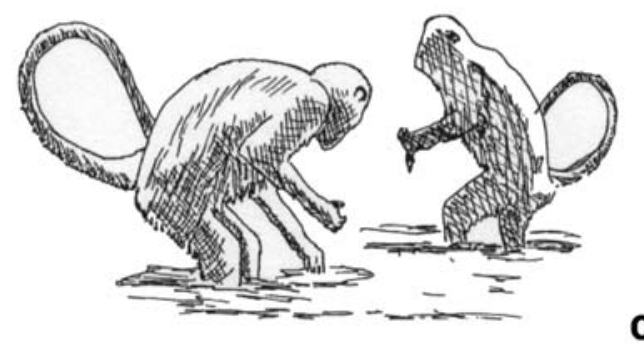

C

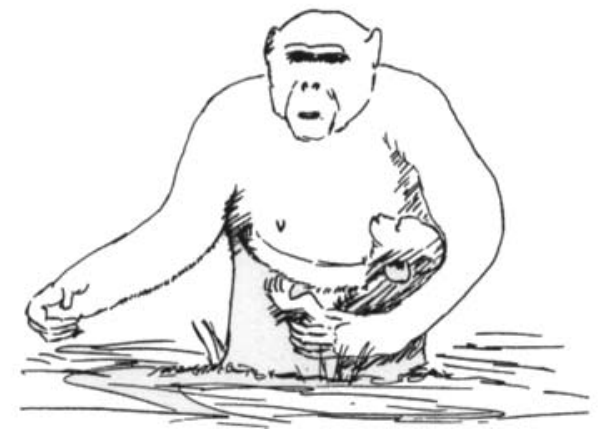

Fig. 4 a Long-tailed macaque (also crab-eating monkey, M. fascicularis) female standing bipedally in the water and eating food retrieved from the ground. b Proboscis monkey ( $N$. larvatus) wading bipedally. c Hanuman langurs (S. entellus) in Nepal, wading bipedally while collecting algae in a stream during the dry period. d Savannah baboons (P. cynocephalus)

than those of $\mathrm{AL}$ 288.1., probably equivalent in size to a female common chimpanzee, indicating that the ancestor may have been larger than previously envisaged" (Sénut et al. 2001), and thus, this fact may putatively have enhanced a riverine way of life of this early biped. Hence, it seems likely that, in wading ancestors, after many generations, longer legs were selected for until they became so long that they gradually lost their suitability for fast quadrupedal locomotion. The prehuman primate, which until that point had covered only short distances on dry land - such as the one to its nightly sleeping tree-remained upright. From that time onwards, a selection for a habitual upright walker and runner could start. This subsequent evolutionary phase includes the gradual emergence of long distance runners (cf. Bramble and Lieberman 2004; Steudel-Numbers et al. 2007), e.g., for hunting, or for endurance walkers that were able to cover great distances, to discover new resources and

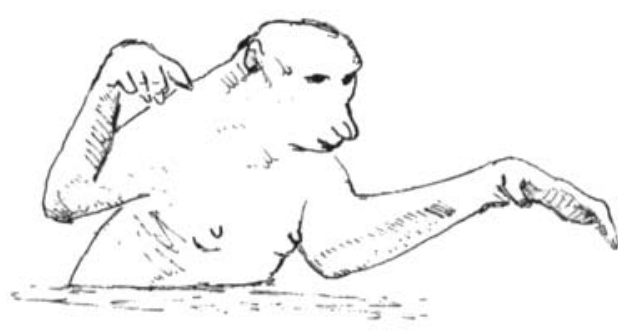

b

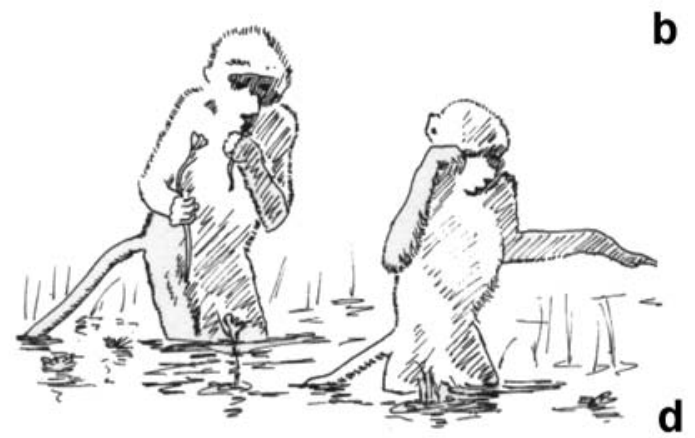

wading bipedally while picking flowers as food. e Chimpanzee ( $P$. troglodytes) female wading bipedally with her infant drinking from her breast. All pictures are redrawn from photographs or films (see text and Table 1 for sources)

to migrate to new places to live in. In that phase, selective forces related to energy costs might have been effective, as gradually acquired human walking is energetically much less costly, depending, however, on a more extended hip joint and on longer legs (Sockol et al. 2007).

The dangers of shallow water and of terrestrial or arboreal life

The objection may be raised that water may be unsafe. But if dangers of water are mentioned, in the first place, it should be considered that an arboreal life bears considerable dangers as well. As a field study on Hanuman langurs in Nepal demonstrated: "locomotion in high trees is dangerous..., sudden falls of monkeys from the trees are not rare and often cause contusions, broken bones and, less frequently, immediate death" (Nikolei 2002). Life in the trees itself is one of the 


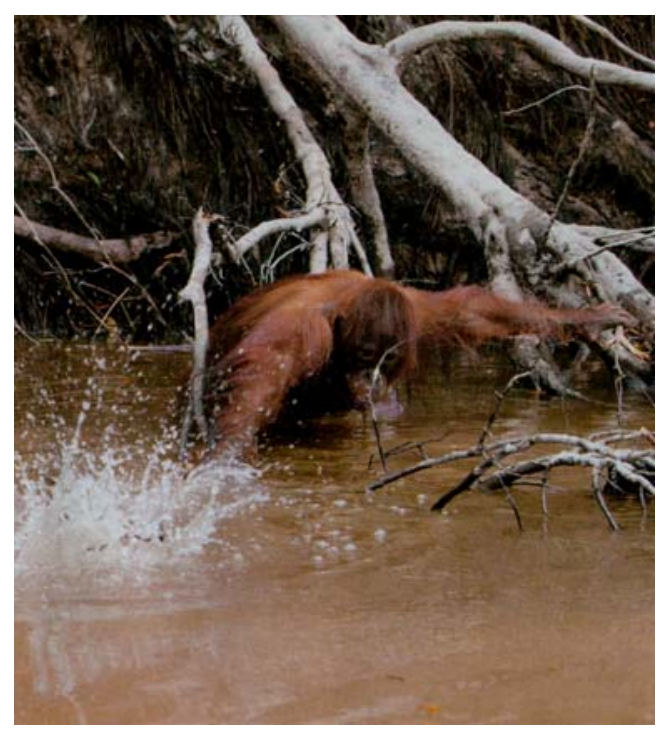

Fig. 5 Bornean orangutan (P. pygmaeus) hunting fish as food. The adult female is standing bipedally in hip-deep water near the steep shore holding onto a dead branch. In the situation shown, the prey was slain using a self-made club; the dead fish was picked from the water and eaten (Foto: Ullal)

most frequent causes of mortality for infant monkeys and thus, conveys an extremely high selective burden.

The relative burden of predators for primates in shallow water or in the trees can certainly not be calculated exactly for our ancestors in that period. However, it seems clear that there is a much greater spectrum of predator species on dry land than in the shallow water of streams and ponds. In any case, e.g., baboons are extremely vigilant on the African shores (Radke, personal communication; own observation). In the films cited in this article showing shore life of monkeys and apes, it can be seen that infants are well looked after by macaques as well as by western gorillas in order to learn how to behave in the water. The behaviour of the adults very much resembles human parents watching and playing with their children in a comparable situation. At least, to the author's knowledge, drowning has never been reported for wild monkey or ape infants. Contrarily, at least several species just love to play, swim, and dive in the water.

\section{Water-associated parasites}

Another argument supporting this hypothesis is related to water-associated parasites. Extant human "parasites for which the existence of human beings is absolutely necessary must have had a long common evolution with hominids" (Aspöck and Walochnik 2007). The authors continue: "Almost all anthropostenoxic (Homo-specific, $\mathrm{CN}$ ) parasites, the presence of which is bound to water, originate from Africa-i.e. from that part of the earth, where the process of hominisation began and where the upright gait evolved", listing: Plasmo- dium vivax, Plasmodium ovale, Plasmodium falciparum, Schistosoma haematobium, Dracunculus medinensis, Brugia timori, Onchocera volvulus, Wucheria bancrofti. As a general notion, the authors conclude that the "Amphibische Generalistentheorie" "appears extremely plausible to us" (Aspöck and Walochnik 2007). In this context, the idea of Henneberg (personal communication) is interesting that flowing waters and coastal areas with waves may have offered a suitable habitat for initial bipedality of shoredwelling primates, as this kind of environment forces the individual to stand firmly, to walk upright — and it may be somewhat safer with respect to parasites.

\section{Thermoinsulation of abdomen and legs}

Also, it seems of great significance that humans show anatomical adaptations, unique among primates, to insulate their lower body and legs. While cercopithecid monkeys like macaques and baboons insulate large parts of their heads, necks, and their bodies, their arms and especially
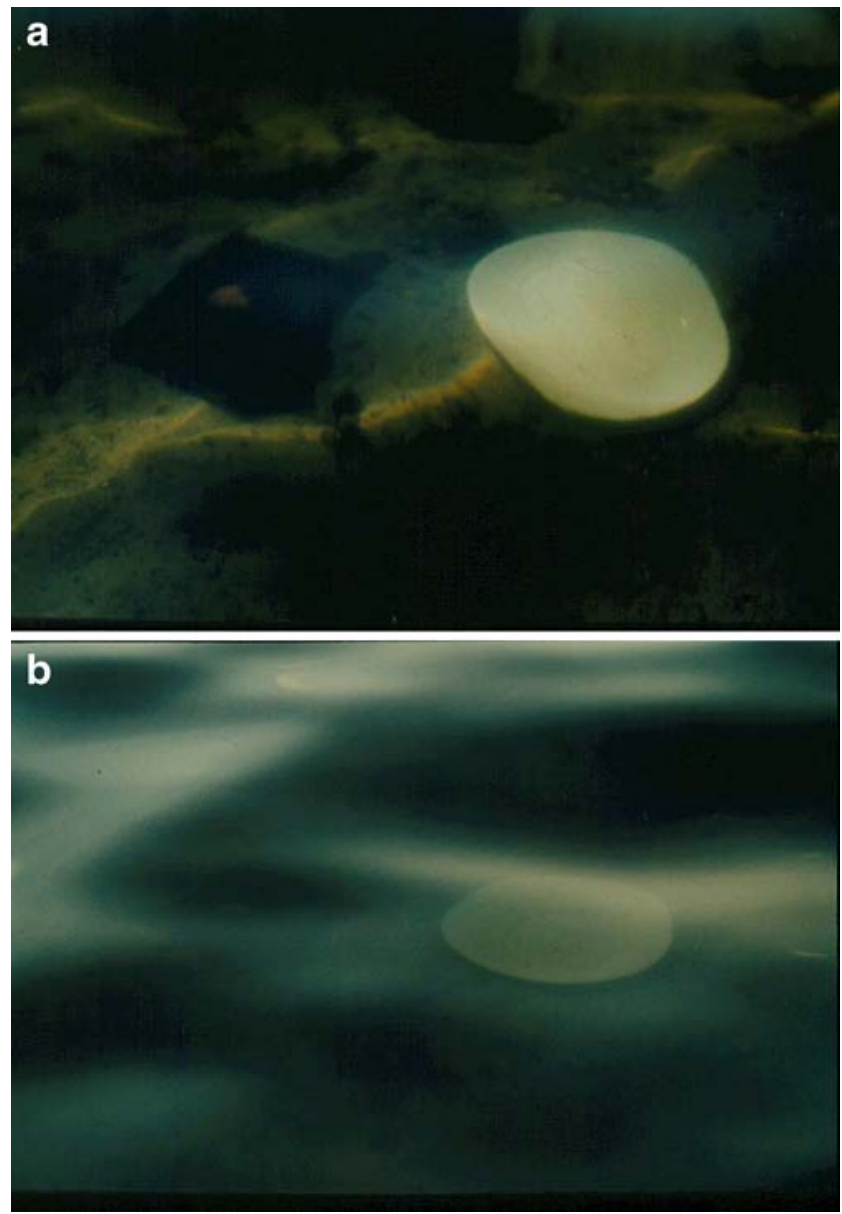

Fig. 6 a At an angle of view of about $45^{\circ}$, two objects on the ground of a shallow water are noticed easily. b At an angle of about $35^{\circ}$, the objects are hardly to be seen. Hence, a higher position of the head may be of positive selective value (cf. text) 
their legs serve as thermoregulatory surfaces for heat exchange. In humans, the skin of the face, neck, and shoulders as well as the ventral and dorsal upper thorax are used for heat exchange, while the lower abdomen, gluteal region, and hip, as well as the whole hind extremities are well insulated (Fig. 7). No other functions than thermoregulation in a wading fashion are suitable to explain the craniocaudal division of subcutaneous fatty tissue of man into a thermoregulatory exchange surface in the upper half of the body on the one hand and an insulating abdomen and hind extremities on the other (Niemitz 2007). Current thermographic data of human subjects wading in knee-deep and hip-deep water, together with skinfold measurements (Lieger et al., unpublished data), are preliminarily consistent with the conclusion that no scenario than wading can be found for a later bipedal ancestor to explain these anatomical conditions for extant human beings.

\section{Habitat preferences}

In the context of the reflections about ecological determinants of our past, it seems reasonable to the present author to include the phenomenon of habitat preferences, which are conveyed genetically (Appleton 1990). Given the fact that an anatomical structure or a behavioural pattern appears in two closely related allochrone taxa, it is very unlikely that the intermediate representatives lost this feature, and their descendants later reacquired it. With respect to "resource availability" in our evolution, Orians noted (1980) "the genetic basis of human habitat selection behavior has presumably been moulded primarily in relation to tropical habitats and has been only weakly modified in the short interval in which we have lived in temperate environments". Still today, "contemporary research on habitat selection, and landscape aesthetics raises the question of whether there is a specific natural setting most suitable for humans" (Han 2007). A cross-cultural study on environmental preference in four continents "... confirms that water is a highly preferred part of any natural scene (Yang and Brown 1992; Hull and Stewart 1995)" (McAndrew et al. 1998). However, as all this has been challenged by one anonymous peer reviewer, it will not be discussed here in detail. The reader may find more about aims, methods and data in Niemitz $(2006,2007)$.

To conclude this section, it may be referenced here, that Preuschoft (2006) stated: "The mechanical foundations" of
Fig. 7 Thermographic pictures of a macaque (M. fuscata), $\mathbf{b}$ a pygmy chimpanzee (bonobo, Pan paniscus), $\mathbf{c}$ and $\mathbf{d}$ human beings. Besides their faces, both nonhuman primates have rather warm (orange and red) limbs, especially, however, the lower ones indicating that both primate species thermoregulate with these skin surfaces. In humans, the lower abdomen and the hind limbs are insulated well by a subcutaneous fatty layer. Human thermoregulatory surfaces are face, neck, shoulder, and the upper thoracic region. The evolutionary acquisition of this marked anatomical difference preconditions the need of our ancestors to insulate only the lower limbs and abdomen. To the author's knowledge, no other cause is probable but a wading habit of the prehuman antecedents in the African waters (thermograms by Thomas Zimmermann, Thermographisches Institut Berlin)
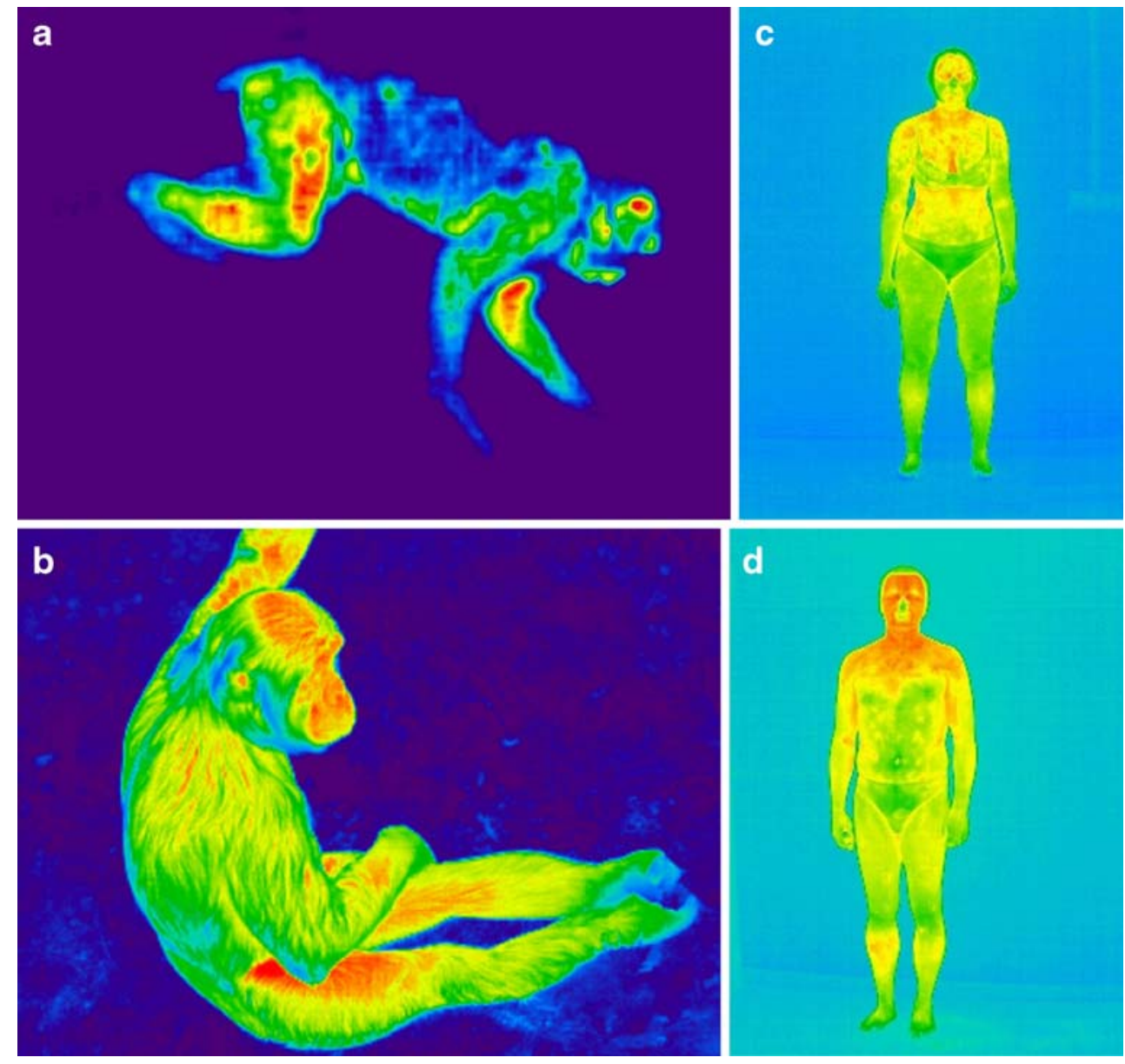
this hypothesis "are... thought through much more painstakingly than in other "theories" dealing with the same complex of problems", noting that it is "in perfect accordance" with biomechanical considerations". Also, "the savannah-hypothesis is replaced by the... shorehypothesis" (Schrenk and Müller 2005), as shore habitats "were the ideal environment for the development of the upright gait" (Schrenk 2008).

The Decoupling Hypothesis The considerations of Sylvester (2006) are focused on a theoretical model that asks what happened in the hominin body when bipedalism evolved. According to his hypothesis: (1) "Bipedalism would have allowed early hominin to occupy niches that mandated highly effective terrestrial and suspensory behaviours which would not have been available to quadrupeds because of the trade-off between shoulder mobility and stability", and (2) "The early hominin body plan should appear to be superiorly/inferiorly split. The upper body should appear adapted to suspensory adaptations and... the hind limbs should appear adapted to terrestrial locomotion". Thus, his calculations seem to bridge between the Orthograde Scrambling Hypothesis and the Reaching for Food Hypothesis on the one hand side with the Throwing Hypothesis and the "Amphibische Generalistentheorie" on the other, as all four theoretical constructions are based, to some extent, on the decoupling process calculated here. Nevertheless, it must be kept in mind that natural selection disfavors a single individual in a single situation if a selective dysfunction is performed. Such an insufficiency may refer to the superior or to the inferior part of the body, but on a statistical level, the compromise for all biological functions considers the whole organism reuniting superior and inferior body sections.

The Dysequilibrium Syndrome Hypothesis The dysequilibrium syndrome is a rare autosomal recessive condition, mutations of which might have enhanced cerebral cortical processing abilities during the evolutionary phase of increase in brain size from australopithecines to Homo erectus (Skoyles 2006). Thus, this hypothesis describes a putative evolutionary development dated far later than the beginning of habitual bipedalism. Whether or not such a process has contributed to the earlier evolution of bipedalism still remains unclear.

\section{Conclusions}

The main problem and cause of not a few academic disputes over human evolution in the past was the uncertainty about the time, when which part of the human evolution took place. It is suggested here, that many hypotheses or main aspects of them may contribute decisively to an image of human evolution, if they are assigned to their correct period. Some 21 to $16 \mathrm{Ma}$ ago, the earliest hominoids appeared as rather monkey like, ecologically nonspecialized creatures with more arboreal and more terrestrial species. In the early Middle Miocene, Nacholapithecus seems to be one of the most complete hominoid skeletons ever found (Ishida et al. 2004), the postcranial remains suggesting a prevalence of orthograde climbing activities. At about the same time, Kenyapithecus was proposed to have shown scansorial activities. At present, the first putative upright hominid seems to be $O$. tugenensis, dated at about $6 \mathrm{Ma}$ (or to genetic findings, somewhat later; Patterson et al. 2006) (Sénut 2003, 2004).

The energetic and anatomical threshold from quadrupedalism to bipedalism, as described above, can be crossed best by postulating a partly arboreal, partly terrestrial quadruped ancestor wading bipedally in the water along the gallery forests and on the shores of the African lakes. This is consistent with energetic calculations, biomechanical findings, and with the present fossil documentation. Certainly, this wading phase has to be regarded mainly as a Miocene process, until the first definitive bipeds had evolved between 7 and $6 \mathrm{Ma}$ bp. Further, fossils besides $O$. tugenensis will be unearthed and permit to establish a more precise time scale. Whether or not extensive shore dwelling continued further on for some time in fossil representatives of the human clade is poorly known, although shore use was demonstrated continuously up to modern Homo sapiens (Niemitz 2004).

Wading was an appropriate trigger not only to stand up but also forced the primate to walk on. It seems likely that habitual bipedalism began not long after the separation from the gorilla and chimpanzee clade(s). From that time onwards, throwing could be evolved with free upper extremities much more successfully than before. Selective factors related to the reduction of incoming solar radiation became effective. Endurance running and adaptations to carry tools (like weapons) started their evolutionary improvements. If these processes took about $4 \mathrm{Ma}$, the wading hypothesis is consistent with a rather perfect bipedal anatomy as shown, e.g., in Homo ergaster (WT 15000), about 1.6 Ma ago. In this way, many of the hypotheses competing in the past may be harmonised, as some of them have yielded important contributions to the understanding of the evolution of the human habitual upright gait.

Acknowledgement I would like to thank Horst Aspöck (Vienna), Maciej Henneberg (Adelaide), and Friedemann Schrenk (Frankfurt) for their comments on an earlier stage of this manuscript. My sincere thanks are due to Tatiana Czeschlik, the Managing Editor of this journal.

Open Access This article is distributed under the terms of the Creative Commons Attribution Noncommercial License which permits any noncommercial use, distribution, and reproduction in any medium, provided the original author(s) and source are credited. 


\section{References}

Altmann J, Samuels A (1992) Costs of maternal care: infant-carrying in baboons. Behav Ecol Sociobiol 29:391-398

Appleton J (1990) The symbolism of habitat. An interpretation of landscape in the art. University of Washington Press, Seattle

Ardey R (1961) African genesis. Dell, New York

Aspöck H, Walochnik J (2007) Die parasiten des menschen aus der sicht der koevolution. Denisia 20 NS 66:179-254

Badrian NL, Malenky RK (1984) Feeding ecology of Pan paniscus in the Lomako forest, Zaïre. In: Susman RL (ed) The pygmy chimpanzee - evolutionary biology and behavior. Plenum Press, New York, pp 275-300

Bartholomew GA, Birdsell JB (1953) Ecology and the protohominids. Am Anthropol 55:481-498

Bearder SK (2000) Flood brothers. BBC Wildlife 18:64-68

Begun DR (2003) Das Zeitalter der Menschenaffen-Spektrum Wiss 12/2003:58-66

Bennett EL, Sebastian AC (1988) Social organization and ecology of proboscis monkeys (Nasalis larvatus) in mixed coastal forest of Sarawak. Int J Primatol 9:233-255

Blumenshine RJ, Cavallo JA (1992) Scavenging and human evolution. Sci Am 267:90-96, dt.: Frühe Hominiden-Aasfresser. Spektrum Wiss. 1992:88-95

Boesch C (1999) The emergence of cultures among wild chimpanzees. Proc Brit Acad 88:251-268

Bramble DM, Lieberman DE (2004) Endurance running and the evolution of Homo. Nature 432:345-352

Brandon-Jones D (1984) Colobus and leaf monkeys. In: Macdonald D (ed) The encyclopaedia of mammals. Allen and Unwin, London, pp 398-408

Breuer Th, Ndoundou-Hockemba M, Fishlock V (2005) Gorilla uses self-made tool while wading in water. Public Library of Science, 3/11, Nov 2005

Brunet M, Guy F, Pilbeam D, Mackaye H, Likius A, Ahounta D, Beauvilain A, Blondel C, Bocherens H, Boisserie J-R, De Bonis L, Coppens Y, Dejax J, Denys C, Duringer P, Eisenmann V, Fanone G, Fronty P, Geraads D, Lehmann T, Lihoreau F, Louchar A, Mahamat A, Merceron G, Mouchelin G, Otero O, Campomanes P, Ponce De Leon M, Rage J-C, Sapanet M, Schuster M, Sudre J, Tassy P, Valentin X, Vignaud P, Viriot L, Zazzo A, Zollikofer C (2002) A new hominid from the Upper Miocene of Chad, Central Africa. Nature 418:145-151

Brunet M, Guy F, Boisserie J-R, Djimdoumalbaye A, Lehmann T, Lihoreau F, Louchart A, Schuster M, Tafforeau P, Likius A, Makaye HT, Blondel C, Bocherens H, De Bonis L, Coppens Y, Denis C, Duringer P, Eisenmann V, Flisch A, Geraads D, Lopez-Martinez N, Otero O, Campomanes PP, Pilbeam D, Ponce De Leon M, Vignaud P, Viriot L, Zollikofer C (2004) 'Toumaï', Miocène supérieur du Tchad, le nouveau doyen du rameau humain. CR Palevol 3:277-285

Brunet M, Guy F, Pilbeam D, Liebermann DE, Likius A, Hassane T, Mackaye H, Ponce de Leon M, Zollikofer C, Vignaud P (2005) New material of the earliest hominid from the Upper Miocene of Chad. Nature 434:752-755

Cant JHG (1987) Positional behavior of female Bornean orangutans (Pongo pygmaeus). Am J Primatol 12:71-90

Cartmill M, Smith FH, Brown KB (2009) The human lineage. John Wiley, New York

Chaplin G, Jablonski NG, Cable NT (1994) Physiology, thermoregulation and bipedalism. J Hum Evol 27:497-510

Clarke RJ, Tobias PV (1995) Sterkfontein member 2 footbones of the oldest South African hominid. Science 269:521-524

Cowlishaw G, Clutton-Brock T (2001) Primates. In: Macdonald D (ed) The new encyclopedia of mammals. Oxford University Press, Oxford, pp 290-301
Crompton RH, Thorpe S, Wang WJ et al. (2003) The biomechanical evolution of erect bipedality. In: Franzen JF, Köhler M, Moyà-Solà S (eds) Walking upright. Cour Forsch-Inst Senckenberg 234:135-146

Crompton RH, Vereecke EE, Thorpe SKS (2008) Locomotion and posture from the common hominoid ancestor to fully modern hominins, with special reference to the last common panin/ hominin ancestor. J Anat 212:501-543

Dainton M (2001) Did our ancestors knuckle-walk? Nature 410:324-325

Dart RA (1959) Adventures with the missing link. Harper and Brothers, New York

Darwin C (1871) The descent of man, and selection in relation to sex. John Murray, London

Deloison Y (2004) Préhistoire du piéton. Essai sur les nouvelles origines de l'homme. Plon, Paris

Demes B, Larsen SG, Stern JT, Biknevicius AR, Schmitt D (1994) The kinetics of primate quadrupedalism: hindlimb drive reconsidered. J Hum Evol 26:353-374

Dunsworth H, Challis JH, Walker A (2003) Throwing and bipedalism: a new look at an old idea. In: Franzen JF, Köhler M, Moyà-Solà S (eds) Walking upright. Cour Forsch-Inst Senckenberg 234:105-110

Eiseley LC (1953) Fossil man. Sci Am 189:65-72

Ellis D (1991) Is an aquatic ape viable in terms of marine ecology and primate behaviour? In: Roede M, Wind J, Patrick JM, Reynolds $\mathrm{V}$ (eds) The aquatic ape: fact or fiction? The first scientific evaluation of a controversial theory of human evolution. Souvenir Press, London, pp 36-74

Etkin W (1954) Social behavior and the evolution of man's faculties. Am Nat 88:129-142

Fedigan L, Fedigan LM (1988) Cercopithecus aethipos: a review of field studies. In: Gautier-Hion A, Bourlière F, Gautier JP, Kingdon (eds) A primate radiation: evolutionary biology of the African guenons. Cambridge University Press, Cambridge, pp 389-411

Fleagle JG (1988) Primate adaptation and evolution. Academic, San Diego

Fleagle JG, Stern JT, Jungers WL, Susman RL, Vangor AK, Wells JP (1981) Climbing: a biomechanical link with brachiation and with bipedalism. In: Day MH (ed) Vertebrate locomotion. Symp Zool Soc Lond 48:359-375

Friday AE (1992) Human evolution: the evidence from DNA sequencing. In: Jones S, Martin RD, Pilbeam D (eds) The Cambridge encyclopedia of human evolution. Cambridge University Press, Cambridge, pp 316-321

Gebo DL (1996) Climbing, brachiation, and terrestrial quadrupedalism: historical precursors of hominid bipedalism. Am J Phys Anthropol 101:55-92

Griffin TM, Kram R (2000) Penguin waddling is not wasteful. Nature 408:929

Groves C, Cameron DW (2004) Bones, stones and molecules. Elsevier Academic Press, London

Günther MM, Li Y, Crompton RH (1997) Bipedal walking in humans and chimpanzees: the significance of differences in specific gait patterns. Folia Primatol 69:187

Haile-Selassie Y (2001) Late Miocene hominids form the Middle Awash, Ethiopia. Nature 412:178-181

Han KT (2007) Responses to six major terrestrial biomes in terms of scenic beauty, preference, and restorativeness. Environ Behav 39:529-556

Harcourt-Smith WEH (2007) The origins of bipedal locomotion. In: Henke W, Tattersall I (eds) Handbook of paleoanthropology. Vol III Phylogeny of hominids. Springer, Berlin, pp 1483-1518

Hewes GW (1961) Food transport and the origin of hominid bipedalism. Am Anthropol 63:687-710

Hore J, Watts S, Martin J, Miller B (1995) Timing of finger opening and ball release in fast and accurate overarm throws. Exp Brain Res 103:277-286

Hore J, Watts S, Tweed D (1999) Prediction and compensation by an internal model for back forces during finger opening in overarm throw. J Neurophysiol 82:1187-1197 
Hrdy SB (1999) Mother nature: natural selection and the female of the species. Chatto and Windus, London

Hunt KD (1994) The evolution of human bipedality: ecology and functional morphology. J Hum Evol 26:183-202

Hunt KD (1996) The postural feeding hypothesis: an ecological model for the evolution of bipedalism. South African J Sci 92:77-90

Hunt KD (1998) Ecological morphology of Australopithecus afarensis: traveling terrestrially, eating arboreally. In: Strasser E, Fleagle J, Rosenberger A, McHenry H (eds) Primate locomotion: recent advances. Plenum Press, New York, pp 397-418

Ishida H, Kunimatsu Y, Takano T, Nakano Y, Nakatsukasa M (2004) Nacholapithecus skeleton from the middle Miocene of Kenya. J Hum Evol 46:67-101

Isler K (2002) Characteristics of vertical climbing in gibbons. Hominid Evol, Suppl 1:49-52

Isler K, Thorpe SKS (2003) Gait parameters in vertical climbing of captive, rehabilitant and wild Sumatran orang-utans (Pongo pgymaeus abelii). J Exp Biol 206:4081-4096

Jablonski NG, Chaplin G (1993) Origin of habitual terrestrial bipedalism in the ancestor of the Hominidae. J Hum Evol 24:259-280

Jolly CJ (1970) The seed-eaters: a new model for hominoid differentiation based on a baboon analogy. Man 5:1-26

Kano T, Mulavwa M (1984) Feeding ecology of the pygmy chimpanzee (Pan paniscus) of Wamba. In: Susman RL (ed) The pygmy chimpanzee - evolutionary biology and behavior. Plenum Press, New York, pp 233-273

Kimura T (1985) Bipedal and quadrupedal walking in primates: comparative dynamics. In: Kondo S (ed) Primate morphophysiology, locomotor analysis and human bipedalism. Tokyo University Press, Tokyo, pp 81-104

Kimura T, Okada M, Ishida H (1979) Kinesiological characteristics of primate walking: its significance in human walking. In: Morbeck ME, Preuschoft H, Gomberg N (eds) Environment, behavior, and morphology: dynamic interactions in primates. Gustav Fischer, New York, pp 297-312

Kirschmann E (1999) Das Zeitalter der Werfer-eine neue Sicht des Menschen. Kirschmann, Hannover

Köhler M, Moyà-Solà S (1997a) Ape-like or hominid-like? The positional behavior of Oreopithecus bamboli reconsidered. Proc Natl Acad Sci USA 94:11747-11750

Köhler M, Moyà-Solà S (1997b) The evolution from pronograde to orthograde posture and locomotion: implications for bipedality. Folia Primatol 69:185

Leakey MG, Feibel CS, McDougall I, Walker A (1995) New fourmillion-year-old hominid species from Kanapoi and Allia Bay, Kenya. Nature 376:565-571

Li Y, Crompton RH, Wang WJ, Günther MM (2002) Reconstructing the mechanics of quadrupedalism in an extinct hominoid. Zeitschr Morphol Anthropol 83:265-274

Lovejoy CO (1978) A biochemical view of the locomotor diversity of early hominids. In: Jolly CJ (ed) Early hominids of Africa. St. Martin's, New York, pp 403-429

Lovejoy CO (1981) The origin of man. Science 211:341-350

Lovejoy CO, Heiple KG, Meindl RS (2001) Did our ancestors knuckle-walk? Nature 410:325-326

Macdonald D (ed) (2001) The new encyclopedia of mammals. Oxford University Press, Oxford, New York

MacLatchy L, Gebo D, Kityo R, Pilbeam D (2000) Postcranial functional morphology of Morotopithecus bishopi, with implications for the evolution of modern ape locomotion. J Hum Evol 39:159-183

Marean CW (1989) Sabertooth cats and their relevance for early hominid diet and evolution. J Hum Evol 18:559-582

Martin RD (1984) Tree shrews. In: Macdonald D (ed) The encyclopedia of mammals. Facts on File, New York, pp 440-445

Matthews Adele, Matthews Andreas (2002) Primate populations and inventory of large and medium sized mammals in the Campo
Ma'an project area, Southwest Cameroon. Report to Tropenbos Foundation, pp 1-222. Freie Universität Berlin, Forschungsgruppe Humanbiologie, Berlin

McAndrew FT, Turner S, Fiedeldey AC, Sharma Y (1998) A crosscultural ranking of the pleasantness of visual and non-visual features of outdoor environments. Paper presented at the annual meeting of the Human Behavior and Evolution Society, Davis Ca., pp 1-16

McCrossin ML, Benefit BR, Gitau SM, Palmer AK, Blue KT (1998) Fossil evidence for the origins of terrestriality among old world higher primates. In: Strasser E, Fleagle J, Rosenberger A, McHenry H (eds) Primate locomotion. Plenum Press, New York, pp 353-396

McHenry HM (2002) Introduction to the fossil record of human ancestry. In: Hartwig WC (ed) The primate fossil record. Cambridge University Press, Cambridge, pp 401-405

Morgan E (1990) The scars of evolution-what our body tells about human origins. Penguin Press, London

Morgan E (1997) The aquatic ape hypothesis - the most credible theory of human evolution. Souvenir Press, London

Moyà-Solà S, Köhler M, Alba DM, Casanovas-Vilar I, Galindo J (2004) Pierolapithecus catalaunicus, a new middle Miocene great ape from Spain. Science 306:1339-1344

Nakatsukasa M (2004) Acquisition of bipedalism: the Miocene hominoid record and modern analogues for bipedal protohominids. J Anat 204:385-402

Nakatsukasa M, Kunimatsu Y, Nakano Y, Ishida H (2000) A new skeleton of a large hominoid from Nachola, northern Kenya. Am J Phys Anthropol 30(Suppl):235

Nakatsukasa M, Ogihara N, Hamada Y, Goto Y, Yamada M, Hirakawa T, Hirasaki E (2004) Energetic costs of bipedal and quadrupedal walking in Japanese macaques. Am J Phys Anthropol 124:248-256

Napier JR, Napier PH (1968) A handbook of living primates. Morphology, ecology and behaviour of nonhuman primates. Academic, London

Niemitz C (2000) A theory on the evolution of human bipedalismDie Amphibische Generalistentheorie. In: Zeller U (ed) Origin and evolutionary transformation of mammals-using biological signals in understanding earth history. Humboldt Univ Berlin, pp 46-48

Niemitz C (2002) A theory on the habitual orthograde human bipedalismthe "Amphibische Generalistentheorie". Anthropol Anz 60:3-66

Niemitz C (2004) Das Geheimnis des aufrechten Gangs-Unsere Evolution verlief anders. C.H.Beck, München

Niemitz C (2006) Indications for an evolutionary correlation of human upright posture and an ecological niche on the shore-new results and views in physical and cultural anthropology. In: Niemitz C (ed) Focuses and perspectives of modern physical anthropology, Mittg Berl Ges Anthropol Ethnol Urgeschichte, Beiheft 1. Berlin, pp 37-46

Niemitz C (2007) Labil und langsam - unsere fast unmögliche evolutionsgeschichte zum aufrechten Gang. Natwiss Rdsch 60:71-78

Nikolei J (2002) Lokomotionsökologie adulter Hanuman-Languren (Semnopithecus entellus) in einem saisonalen Waldhabitat in Ramnagar, Süd-Nepal. Dissertation, Freie Universität Berlin, Forschungsgruppe Humanbiologie, Berlin

Novak RM (1991) Primates. In: Novak RM (ed) Walker's mammals of the world, 5th edn. John Hopkins Univ Press, Baltimore, pp 400-514

Orians GH (1980) Habitat selection: general theory and applications to human behavior. In: Lockard JS (ed) The evolution of human social behavior. Elsevier, Chicago, pp 49-66

Oxnard CE (1979) The morphological-behavioural interface in extant primates: implications for systematics and evolution. In: Morbeck ME, Preuschoft H, Gomberg N (eds) Environment, behavior, and morphology: dynamic interactions in primates. Gustav Fischer, New York, pp 209-228

Oxnard CE (1983) The order of man. Hong Kong University Press, Hong Kong, pp 247-249 
Patterson N, Richter DJ, Gnerre S, Lander ES, Reich D (2006) Genetic evidence for complex speciation of humans and chimpanzees. Nature 441:1103-1108

Patterson N, Richter DJ, Gnerre S, Lander ES, Reich D (2008) Patterson et al. reply. Nature 452:E4

Pickford M, Sénut B, Gommery D, Treil J (2002) Bipedalism in Orrorin tugenensis revealed by its femora. CR Palevol 1:191-2003

Preuschoft H (2004) Mechanisms for the acquisition of habitual bipedality: are there biomechanical reasons for the acquisition of upright bipedal posture? J Anat 204:363-384

Preuschoft H (2006) Referat zu: Niemitz C (2004) Das Geheimnis des aufrechten Gangs. CH Beck, München. Zentralbl Geol Paläontol 69:81-82

Preuschoft H, Preuschoft S (1991) The aquatic ape theory, seen from epistemological and palaeoanthropological viewpoints. In: Roede M, Wind J, Patrick JM, Reynolds V (eds) The aquatic ape: fact or fiction? The first scientific evaluation of a controversial theory of human evolution. Souvenir Press, London, pp 142-173

Richmond BG, Jungers WL (2008) Orrorin tugenensis femoral morphology and the evolution of hominin bipedalism. Science 319:1662-1665

Richmond BG, Strait DS (2000) Evidence that humans evolved from a knuckle-walking ancestor. Nature 404:382-385

Richmond BG, Strait DS (2001a) Reply: evidence that humans evolved from a knuckle-walking ancestor. Nature 404:382-385

Richmond BG, Strait DS (2001b) Reply: did our ancestors knucklewalk? Nature 410:326

Richmond BG, Begun DR, Strait DS (2001) Origin of human bipedalism: the knuckle-walking hypothesis revisited. Yearb Phys Anthropol 44:70-105

Roede M, Wind J, Patrick JM, Reynolds V (eds) (1991) The aquatic ape: fact or fiction? The first scientific evaluation of a controversial theory of human evolution. Souvenir Press, London

Rook L, Bondioli L, Köhler M, Moyà-Solà S, Macchiarelli R (1999) Oreopithecus was a bipedal ape after all: evidence from the iliac cancellous architecture. PNAS 96:8795-8799

Rose MD (1976) Bipedal behavior of the olive baboon (Papio anubis) and its relevance to an understanding of the evolution of human bipedalism. Am J Phys Anthropol 4:247-261

Rose MD (1984) Food acquisition and the evolution of positional behavior: the case of bipedalism. In: Chivers DJ, Wood BA, Bilsborough A (eds) Food acquisition and processing in primates. Plenum Press, New York, pp 509-524

Rose MD (1991) The process of bipedalization in hominids. In: Coppens Y, Sénut B (eds) Origine(s) de la bipédie chez les hominidés. CNRS, Paris, pp 37-48

Rose MD (1997) Functional and phylogenetic features of the forelimb in Miocene hominoids. In: Begun DR, Ward CV, Rose MD (eds) Function, phylogeny and fossils: Miocene hominoid evolution and adaptations. Plenum Press, New York, pp 79-100

Rowe N (1996) The pictorial guide to the living primates. Pogonias Press, East Hampton

Rowell TE (1984) The 45 species of "typical" monkeys. In: Macdonald D (ed) The encyclopedia of mammals. Facts on File, New York, pp 382-385

Rubenson J, Heliams DB, Maloney SK, Withers PC, Lloyd DG, Fournier PA (2007) Reappraisal of the comparative cost of human locomotion using gait-specific allometric analyses. J Exp Biol 210:3513-3524

Salisbury M (2003) Life of mammals (film). BBC, Bristol

Schmitt D (2003) Insights into the evolution of human bipedalism from experimental studies of humans and other primates. J Exp Biol 206:1437-1448

Schrenk F (2008) Die Frühzeit des Menschen. Der Weg zu Homo sapiens. 5th ed, C.H.Beck, München

Schrenk F, Müller St (2005) Die Neandertaler. C.H.Beck, München
Schrenk F, Sandrock O, Kullmer O (2004) An "open source" perspective of earliest hominid origins. Coll Anthropol 28 (Suppl 2):65-76

Schuster G, Smits W, Ullal J (2007) Die Denker des Dschungels. H.F. Ullmann-Tandem, Königswinter

Semaw S, Renne P, Harris JWK, Feibel CS, Bernor RL, Fesseha N, Mowbray K (1997) 2.5 million year old stone tools from Gona, Ethiopia. Nature 385:333-336

Sénut B (2003) Palaeontological approach to the evolution of hominid bipedalism: the evidence revisited. In: Franzen JF, Köhler M, MoyàSolà S (eds) Walking upright. Cour Forsch-Inst Senckenberg 234:125-134

Sénut B (2004) Origins of hominids: from Ramapithecus-Kenyapithecus to Orrorin. Zona arqueológica. Vol III, Madrid, Paleoanthropología No $4: 372-380$

Sénut B (2006) Bipédie et climat. CR Palevol 5:89-98

Sénut B (2007) The earliest putative hominids. In: Henke W, Tattersall I (eds) Handbook of paleoanthropology. Vol III Phylogeny of hominids. Springer, Berlin, pp 1519-1538

Sénut B, Pickford M (2004) La dichotomie grands singes-homme revisitée. CR Palevol 3:265-276

Sénut B, Pickford M, Gommery D, Mein P, Cheboi K, Coppens Y (2001) First hominid from the Miocene (Lukeino formation, Kenya). CR Acad Sci, Sciences de la Terre et des Planètes 332:137-144

Sénut B, Nakatsukasa M, Kunimatsu Y, Nakano Y, Takano T, Tsujikawa H, Shimizu D, Kagaya M, Ishida H (2004) Preliminary analysis of Nacholapithecus scapula and clavicle from Nachola, Kenya. Primates 45:97-104

Shabel A (2005) The paleobiology of the robust australopithecines (Paranthropus): a test of the durophage model with carbon isotope analysis. J Vertebrate Paleontol 25(Suppl No 3):114A

Shumaker RW (2004) Hominidae I. In: McDade MC (ed) Grzimek's animal life encyclopedia. Vol. 14. Mammals III, 2nd edn. Thompson, Gale, Farmington Hills, pp 225-240

Simons E (1992) The fossil history of primates. In: Jones S, Martin R, Pilbeam D (eds) Human evolution. Cambridge University Press, Cambridge

Skoyles JR (2006) Human balance, the evolution of bipedalism and dysequilibrium syndrome. Med Hypotheses 66:10601068

Sockol MD, Raichlen DA, Pontzer H (2007) Chimpanzee locomotor energetics and the origin of human bipedalism. PNAS 104:1226512269

Stauffer RL, Walker A, Ryder OA, Lyons-Weiler M, Blair Hedges S (2001) Human and ape molecular clocks and constraints on paleontological hypotheses. J Heredity 92:469-474

Stern JT (2000) Climbing to the top: a personal memoir of Australopithecus afarensis. Evol Anthropol 9:113-133

Steudel-Numbers KL, Weaver TD, Wall-Scheffler CM (2007) The evolution of human running: effects of changes in lower-limb length on locomotor economy. J Hum Evol 53:191-196

Sugardjito J, van Hooff JARAM (1986) Age-sex class differences in the positional behaviour of the Sumatran orang-utan (Pongo pygmaeus abelii) in the Gunung Leuser National Park, Indonesia. Folia Primatol 47:14-25

Susman RL (1984) The locomotor behaviour of Pan paniscus in the Lomako forest. In: Susman RL (ed) The pygmy chimpanzee - evolutionary biology and behavior. Plenum Press, New York, pp 369-391

Sylvester AD (2006) Locomotor decoupling and the origin of hominin bipedalism. J Theor Biol 242:581-590

Taylor CR, Rowntree VJ (1973) Running on two or on four legs: which consumes more energy? Science 179:186-187

Thorpe SKS, Crompton RH (2006) Orang-utan positional behavior and the nature of arboreal locomotion in Hominoidea. Am J Phys Anthropol 131:384-401 
Thorpe SKS, Holder RL, Crompton RH (2007a) Origin of bipedalism as an adaptation for locomotion on flexible branches. Science $16: 1328-1331$

Thorpe SKS, Holder RL, Crompton RH (2007b) Origin of human bipedalism as an adaptation for locomotion on flexible branches. Science 316:1328-1331

Tuttle RH (1967) Knuckle-walking and the evolution of hominoid hands. Am J Phys Anthropol 26:171-206

Vaughan CL (2003) Theories of bipedal walking: an odyssey. J Biomech 36:513-523

Wakeley J (2008) Brief communications arising: Patterson et al. (2006) Genetic evidence for complex speciation of humans and chimpanzees. Nature 452:E3-E4

Wall-Scheffler CM, Geiger K, Steudel-Numbers KL (2007) Infant carrying: the role of increased locomotory costs in early tool development. Am J Phys Anthropol 133:841-846

Wang WJ (1999) The mechanics of bipedalism in relation to loadcarrying: biomechanical optima in hominid evolution. $\mathrm{PhD}$-thesis, Univ of Liverpool, Liverpool

Wang WJ, Crompton RH (2004) The role of load-carrying in the evolution of modern body proportions. J Anat 204:417-430

Ward EJ, Underwood CR (1967) The effect of posture on the solar radiation area of man. Ergonomics 10:399-409

Washburn SL (1967) Behaviour and the origin of man. Proc Royal Anthrop Soc 3:21-27

Washburn SL, Howell C (1960) Human evolution and culture. In: Tax S (ed) Evolution after Darwin. Univ of Chicago Press, Chicago

Watanabe K (1989) Fish: a new addition to the diet of Japanese macaques on Koshima Island. Folia Primatol 52:124-131

Watson JC, Payne RC, Chamberlain AT, Jones RK, Sellers WI (2008) The energetic costs of load-carrying and the evolution of bipedalism. J Hum Evol 54:675-683

Westenhöfer M (1942) Der Eigenweg des Menschen. W. Mannstaedt, Berlin
Wheeler PE (1984) The evolution of bipedality and loss of functional body hair in hominids. J Hum Evol 13:91-98

Wheeler PE (1985) The loss of functional body hair in man: the influence of thermal environment, body form an bipedality. J Hum Evol 14:23-28

Wheeler PE (1990) The significance of selective brain cooling in hominids. J Hum Evol 19:321-322

Wheeler PE (1991a) The thermoregulatory advantages of hominid bipedalism in open equatorial environments: the contribution of increased convective heat loss and cutaneous evaporative cooling. J Hum Evol 21:107-115

Wheeler PE (1991b) The influence of bipedalism on the energy and water budgets of early hominids. J Hum Evol 21:117-136

Wheeler PE (1994) The foraging times of bipedal and quadrupedal hominids in open equatorial environments (a reply to Chaplin, Jablonski and Cable 1994). J Hum Evol 27:511517

Witte H, Preuschoft H, Recknagel S (1991) Human body proportions explained on the basis of biomechanical principles. Z Morph Anthropol 78:407-423

WoldeGabriel G, Haile-Selassie Y, Renne PR, Hart WK, Ambrose SH, Asfaw B, Heiken G, White T (2001) Geology and palaeontology of the Late Miocene Middle Awash valley, Afar rift, Ethiopia. Nature 412:175-178

Wrangham RW (1980) Bipedal locomotion as a feeding adaptation in Gelada baboons, and its implication for hominid evolution. J Hum Evol 9:329-331

Young R (2003) Evolution of the human hand: the role of throwing and clubbing. J Anat 202:165-174

Young NM, MacLatchy L (2004) The phylogenetic position of Morotopithecus. J Hum Evol 46:163-184

Zollikofer CPE, Ponce de Léon MS, Lieberman DE, Guy F, Pilbeam D, Likius A, Mackaye HT, Vignaud P, Brunet M (2005) Virtual cranial reconstruction of Sahelanthropus tchadensis. Nature 434:755759 